\title{
MELODRAMA OF MIGRATION
}

\author{
Suffering, Performance, and Stardom \\ in Ricardo Lee's DH: Domestic Helper
}

\author{
Oscar Tantoco Serquiña, Jr. \\ University of the Philippines \\ otserquina@up.edu.ph
}

\begin{abstract}
This essay revisits DH: Domestic Helper, a 1992 play from the Philippine Educational Theater Association (PETA) that explores how Philippine labor out-migration ensnares female migrant subjects in states of perennial leave-takings and tentative resettlements abroad. The discussion comprehends the suffering that overseas Filipina workers experience, as well as the agency that they demonstrate through performance in everyday life outside their source country. This essay concludes with an inter-subjective analysis of the very star and ultimate persuasion of PETA's phenomenal theater production, Nora Aunor, the melodramatic mode of theater making, and the topic of labor out-migration. By putting these issues side by side, this essay discursively intertwines stardom, theater, the domestic, and the diasporic.
\end{abstract}

\section{Keywords}

Philippine plays, feminized labor, Nora Aunor, Ricardo Lee, Brechtian structure, plays-withina-play, Superstar, nationalist theater, people's theater

\section{About the Author}

Oscar Tantoco Serquiña, Jr. is a faculty member from the Department of Speech Communication and Theatre Arts at the University of the Philippines. He is currently a doctoral candidate in Theatre Studies at the University of Melbourne. His essays have appeared in Theatre Research International, Humanities Diliman, the Philippine Political Science Journal, Philippine Studies, and the Philippine Humanities Review. 
Penned by the critically acclaimed and commercially successful nationalist writer, Ricardo Lee, the play DH: Domestic Helper spotlighted the plight of Filipino domestic helpers and shored up the Philippine Educational Theater Association (PETA)'s ambition of developing a people's theater aesthetics. As PETA's initial offering for its $26^{\text {th }}$ major theater season, the play first ran from November 1992 to February 1993 at the Dulaang Rajah Sulayman in Fort Santiago within the former Spanish colonial enclave of Intramuros. Cast for its leading role is Nora Aunor, well-known as the Philippine entertainment industry's one and only Superstar. It toured across the globe with a total of 16 sponsored performances and thereby reached out to a large number of overseas Filipinos from all over Asia (Hong Kong), Europe (Paris, Rome, Zurich, and Barcelona), and North America (Toronto, Ontario, Edmonton in Canada; Florida, San Francisco, Los Angeles, Houston in the US). For its entire theatrical run, $D H$ had set a phenomenal box-office record for drawing sales that paid for its whole theater season, enabling PETA to recover 300 percent of its production expenses (Fernandez 159).

$D H$ was a product of a theater institution's attempt in the 1990 os to raise consciousness among artists and publics, contribute to the development of artistic and technical skills of practitioners, and help establish theater groups in communities and institutions that may promote national culture (Fajardo 180; Samson et al. 135). More specifically, the play demonstrated how PETA responded to the increasing feminization of migrant labor and to the Philippine state's neglect of overseas Filipino workers. $D H$, then, may be regarded as an elaboration of a previous PETA theatrical production on labor migration, AMAH: Maid in Hong Kong, which employed an editorializing chorus to establish the inhumane experiences of migrant workers, particularly domestic helpers. However, unlike the latter, $D H$ enlisted the country's Superstar and entailed a much wider reach in terms of logistics, publicity, marketing, and audience profiling. While both plays were under PETA's auspices, $D H$ particularly demonstrated how PETA could transform nationalist sentiments on migration into a play involving a huge cast and production team, which primarily included the trio of Aunor, Lee, and the theater director Soxy Topacio.

$D H$ attempted to provide a gut-wrenching representation of a people who are "being swept off from their marginal paradise only to find out that they are unwelcome and unable to build their private utopias" (Abejo n.p.). ${ }^{2}$ It also centered on how Filipina domestics struggle to keep their humanity intact, even as they confront the herculean task of fending for their families in the Philippines by earning a living overseas. Lee's work depicted various experiences of several types of female migrant workers who largely constitute the world's industries. With its pathos-laden narrative and its strong critique against inhumane working conditions, the play served as "a dramatic thunderbolt that hits the viewer between 


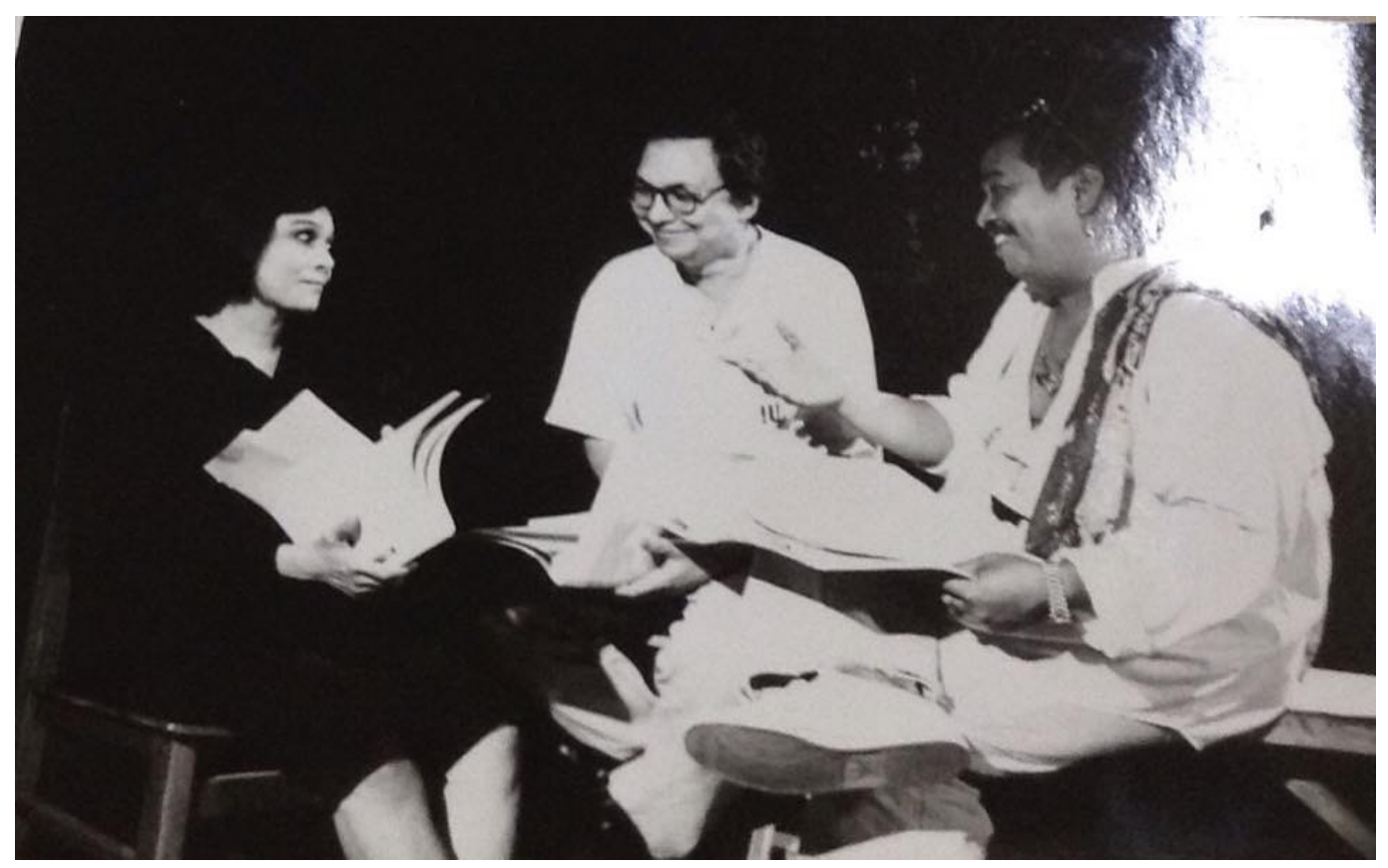

Fig. 1. Nora Aunor, Ricardo Lee, and Soxy Topacio constitute the troika behind the production. Photo courtesy of the PETA Library and Archives.

the eyes and makes him or her realize the injustice that Filipina domestic helpers have to undergo in the course of trying to survive" (Philippine Educational Theater Association, "Press Release" n.p.).

Lee recalled the challenges in writing this project. PETA instructed him to at once think of roles that would fit the Superstar's public persona and that would put together four migrant locations in one dramatic narrative. Lee accomplished this requirement by creating in $D H$ three plays within a play, with three episodes interwoven in one bigger plot, where Aunor had to change characters in front of the audience, in order to string together diverse profiles of overseas workers and evoke a feeling of intimacy despite the gaping distance separating the migrant characters from one another. Synthesizing the issues and conflicts of Filipino labor migration, which Lee mostly derived from voice-tapes, letters, and personal testimonies of real migrant workers, $D H$ did not have the linear structure of a realist play. Touted in the newspapers as the playwright's critique of plays that devoted vast resources to escapism and spectacle (see "Ricky Lee: Playwright of 'DH (Domestic Helper)"” n.p.), this play tried to innovate the melodramatic mode. As Lee himself asserted: "I never wanted to write something that has been done over and over. It's much better to commit mistakes in doing something new than go right all the way on 


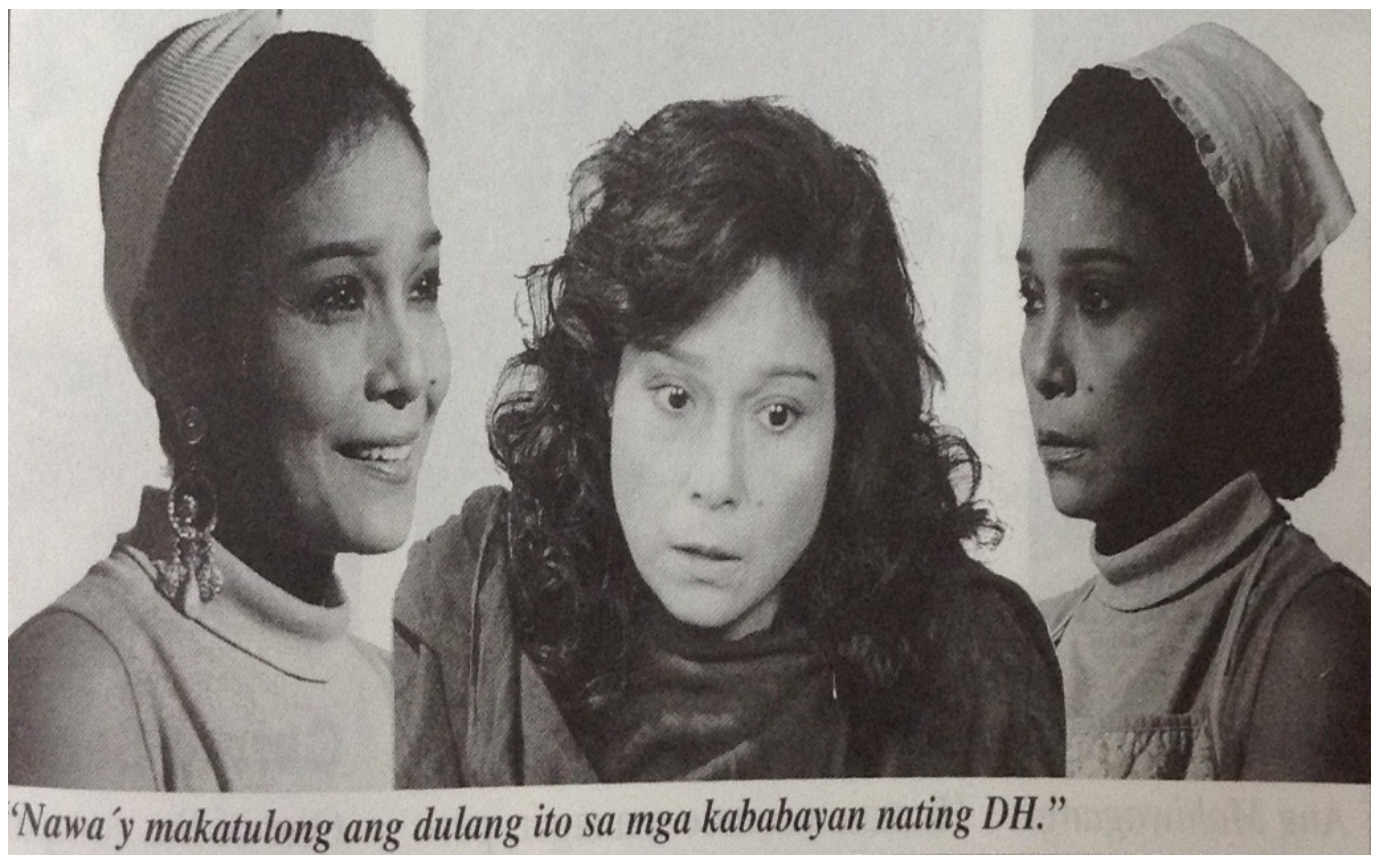

Fig. 2. Aunor plays the roles of Fe (Hong Kong), Noemi (Cairo), and Dolor (Barcelona). Photo courtesy of the PETA Library and Archives.

the safe side" (in Philippine Educational Theater Association, DH: Domestic Helper Souvenir Program n.p.).

$D H$ introduces its audience to a group of Filipino migrant workers in Italy gathered to put up a stage play that portrays the life narratives of overseas domestic helpers around the world. They first reenact the story of Noemi, a Filipino househelper in Cairo, Egypt, who ends up murdering the family she serves, upon discovering hidden letters from her family back home bearing the news about her sick daughter's death. The performing group also tries out another story from Hong Kong, which features Fe, who, after escaping the dehumanizing household of her previous employers, becomes an A.B. (Akyat Barko) or a sex worker to seamen just like her Filipina friends in the harbor at night. And finally, they take on the story of Dolor, a relatively successful domestic in Barcelona who later discovers the drug addiction of her son, whom she would painfully surrender to the police back in the Philippines.

These storylines are essayed by the hesitant Loida, also a DH in Italy whom the director Agnes painstakingly persuades to replace the original star of the show, the undocumented migrant Ofelia, who went into hiding. Even while acting out the 

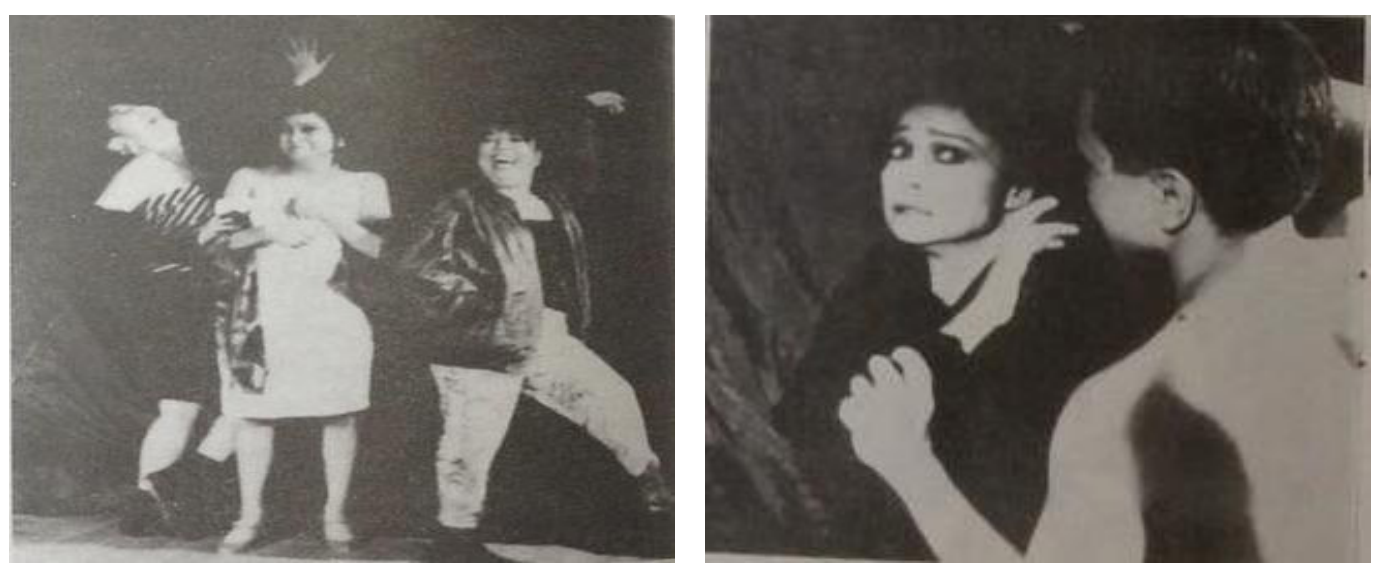

Figs. 3 and 4. Left photo shows Aunor as Fe with her fellow Akyat Barkos in Hong Kong. Right photo shows the Superstar playing Noemi who's being assaulted by the son of her employer. Photo courtesy of the PETA Library and Archives.

lives of the cited domestic helpers from Cairo, Hong Kong, and Barcelona, Loida in between breaks consistently begs off from the role and comes up with many excuses. She has decided to quit the production, but after some prodding from her director and co-actors, eventually concedes to pursue the role. In one of the group's rehearsals, however, Ofelia is announced dead, after jumping off a ten-story building to evade the cops that have been tracking her down.

During the finale performance night, when the three domestic helper characters Noemi, Fe, and Dolor are on stage, Loida starts delivering unscripted and unrehearsed lines in front of the audience. This unexpected twist in the narrative reveals the character's complicity with the police. This revelation of guilt and deceit explains Loida's indecision to continue the whole project. This turn of event enrages members of the cast and pushes them to condemn their deceptive kababayan.

The play does not come to a final stop, however. The character of Loida, almost rejected by the migrant community to which she belongs, immediately transforms as Nora, who herself directly addresses the audience, pursuing the play's playwithin-a-play framework. In the final curtain call, $D H$ provides an "ending" by suspending the conflicts that the play's narrative generates, and by further allowing Aunor herself, the real star of the show, to enunciate a scathing statement against the Philippine state.

This essay begins its analysis of $D H$ with the notion of suffering as exemplified by Filipina migrant workers through their laboring "domestic bodies" (Tadiar, 
"Domestic Bodies" 154). Migrant suffering is a category that accounts for the feminization of labor, the creation of social life through pain, and the constitution of the human flesh that is perennially colonized by forces of capitalism, modernity, and globalization but that also frustrates this very colonization. In the context of a laboring migrant subject that exits the nation out of deep obligations and consequently enters oftentimes perilous spheres abroad, suffering includes personal transformation within an economy of aspiration for oneself and others. It also operates as an experience of labor that compels the domestic worker to affirm her marginalization in repressive conditions, on the one hand, and to reconsider this very marginalization as a point from which a position of strength may emerge, on the other.

The second part of this essay discusses how $D H$ 's Brechtian structure of having various plays within a play effectively depicts domestic workers as at once exploited but self-aware laboring subjects. If the play's narrative arc progresses within the format of a stage rehearsal, where the characters get to magnify and question the figurations they make of Filipino migrant workers, then it might be necessary to query upon how performance in $D H$ operates as an opportunity for the characters to critique the broad phenomenon of Filipino labor migration and to reflect on their subject position in the labor diaspora. This essay argues that $D H$ succeeds in portraying the self-consciousness and critical reflection of migrant workers through the techniques of performance, such as heightened rehearsals, practices, and training, happening within the play's dramatic narrative. Lee employs performances within the play not only to present a sequence of events or to accomplish a playwithin-a-play format, but also to enhance the visibility of issues about migration he wishes to emphasize. Performance here is understood as "an ongoing repertoire of gestures and behaviors that get reenacted/reactivated again and again" (Taylor 10), or simply put, as an embodiment of "a constant state of again-ness" (26). It is imitative reiteration, but also a critical, creative, and transformative action within repeated frameworks (15). In $D H$, the migrant characters are not only expected to produce a play in the play, but they, too, are contemplating and working on their condition while in performance. In this chosen structure, Lee does not only show what performance and theater is but also, to borrow words from performance studies scholar Diana Taylor, "what it does, what it allows us to see, to experience, and to theorize, and its complex relation to systems of power" (6). As this essay will assert, it is through performance that Lee questions the ontologies of labor migration and in fact provides a methodology in which migrants may question not only what they have but also what they do.

The third and final section begins with Lee's "melodrama of migration," a term that this essay deploys to intuit the performative and the political in a mode of theater that gathers unto its fold migrant workers who demonstrate the crisis 
of Philippine modernity and militate against the Philippine state's conception of development by way of systematic exportation of laborers. If melodrama bears conventional morality and excessive sentimentalism as its stylistic hallmarks, and if it is historically used by theater and media practitioners to employ the ideology of capitalism, patriarchy, and the bourgeoisie, how then does PETA rework this aesthetic mode via $D H$ ? How does $D H$ at once carry and subvert the content and conventions of melodrama? How does the play's modality intersect the formulations of melodrama, specifically those that bank on excessive emotions, with Brechtian methods of theater-making that reflect on excessive sensations and subsequently remind the audience of the artificiality of the representational drama of a diasporic life-world mounted on stage?

A discussion on the entwined discourses of migrant labor, national suffering, and performance that constellate and are constellated by Aunor's stardom comprises the conclusion of this essay. Partly sensing Aunor's short stint in theater and partly determining her relevance to migration discourse, this section revaluates the cultural capital of the Superstar who has lent herself quite generously to the nationalist agenda of PETA. In this scheme of analysis, it may be possible to parse how Aunor transforms and is transformed by a theater that capitalizes on her celebrity, her acting technique, her filmography, and her followers in the Philippines and abroad. Given these transactions between PETA and the Superstar, it might be worth raising questions such as: What makes Aunor a reliable actress for performances with underlying nationalist agenda? In the case of $D H$, which came a little over a decade after Aunor's film Atsay (1978) and a few years before The Flor Contemplacion Story (1995), what makes the Superstar a potent medium through which the nation and its fragments, particularly its suffering women, might be understood? That Aunor, a first-rate Filipino actress whose career's trajectory may be loosely described as migratory, brings to life the DH figure on the theatrical stage and in the mode of melodrama is indeed instructive in plotting out the intersections of suffering, performance, and stardom.

This essay revisits $D H$ precisely because the play is an exemplification not only of how Philippine theater is implicated in the nation's histories of migration but also of how it has responded as a cultural practice to sociohistorical and geopolitical periods or phenomena. As this essay is keen to demonstrate, $D H$ lays bare how a whole network of powerbrokers, art practitioners, patrons, and sponsors bring to life theater productions about OFWs. $D H$ is an instantiation of how theater companies and the Philippine entertainment industry may intervene in the affairs of the state through their interconnected artistic involvements, infrastructures, and collaborations. Because $D H$ features Aunor and banks on her stardom, this play also reveals how theater serves as a commodity with a social life that creates and is created by audiences and fans. 
This essay focuses on the extant script of Lee's play, PETA's archival materials on the play, some available videos and photographs, and a few write-ups about Aunor, whose involvement in Philippine theater remains understudied. It is crucial to note, then, that this essay is limited by the ephemerality of performance and the incompleteness of the archive. However, despite this durational distance from the scene of action, this play pursues its examination of $D H$ through the remainders or proofs of its life. Dealing with these traces is not so much to call for a restaging of $D H$ in the 21st century, although that may be an interesting possibility, as it is to reactivate through a dramaturgical analysis the entanglements of screen, stage, and society as instantiated by and through Lee, Aunor, Topacio, and PETA's collective theater venture.

\section{MIGRANT SUFFERING}

If suffering is an outcome of what institutional powers and social forces do to and on people, and if it is an experience that the human body has to transact with in order to belong to a certain social community which is propped up by the very being-in-pain, then $D H$ reveals the anguish of helpless female migrant workers with almost nonexistent agency both in their homeland and abroad. In providing figures of suffering, the play serves as a cultural response that at once presents and makes a spectacle of the perceived "real condition" of labor migration in the country. Through the figures of female migrant workers that $D H$ captures and circulates, Lee's play does not only create a visual economy of the suffering that Filipino migrant women bear. In couching the narratives of "victims" in explicitly nationalist sentiments against the Philippine state, the play also provokes the national body at large and the viewing public more specifically to address the growing problem of labor migration in the country.

DH depicts migrant workers as subjects that courageously traverse an uncertain path of progress outside the Philippine nation. There are elements of gambling in this rite of passage to be sure ("Ritual Passage" 99), and migrant workers partake of this journey with so much derring-do, not for the sake of oneself alone, but most especially for others who depend on their entry to precarious territories. Indeed, there is something perilous and promising at work in a migrant's voyage insofar as prospects of prosperity are only realizable within conditions of labor exploitation, racial discrimination, and sexual subjugation.

$D H$ specifically depicts Filipina domestics as parents who mourn their broken relationships in the motherland; as victims whose laboring bodies are commodified under racialized, sexualized, feminized employment; as "purveyors of degenerate 
cultural values, carriers of diseases, destroyers of social cohesion, enactors of criminality and sexual immorality, and thieves who steal jobs from locals" ("Ritual Passage" 104); and as diasporic subjects that paradoxically contribute to the production of global capitalism and yet remain a peripheral population subjected to state control. The relations of the subjectivities of the characters in $\mathrm{DH}$-from mother to migrant to servant to prostitute-signify the importance of women in the profit-making agenda of the nation-state and the diaspora. These social roles validate the zones of exchange into which these female subjects are absorbed or coerced as objects of value. They further show how these women are constructed and set in motion not just by the politics of location, gender, and identity but also by the interplay of social institutions and political regimes (Grewal and Kaplan 672).

In their partial belongingness to the homeland that leases them out and to the countries that welcome them temporarily, female migrant subjects are neither bound nor free. This liminal status is fundamental in the cultural, symbolic, and biological productivity of both the nation and the diaspora. To put it differently, it is the simultaneous exchange, circulation, and control of these women that often form the foundation of social order. Within the global reorganization of capitalism, Filipinas are no longer excluded from spheres of work and travel; in fact, it is their inclusion in these spheres that has accorded them incipient labor entitlements to go on in restrictive circulation within economies that require their all-out participation mostly as low-rung unskilled workers.

The first part of $D H$ shows Noemi in Cairo, Egypt during the season of the Ramadan. She is all agog serving her employers. She faces the audience and talks about the prohibitions against Catholic religious practices, such as reading the Bible, which her employer imposes upon her. She remembers her family, particularly her mother and her sick daughter Suzette, from whom she draws strength. She says:

Si Suzette ang nabibigay ng lakas sa akin dito, Inay. Trabahong kalabaw kasi ako. Gumigising ako alas singko pa lang ng umaga. Laba, luto, plantsa. Walang tigil na trabaho 'yun, Inay, hanggang ala una ng madaling araw. Ang pahinga ko lang ay iyong ilang segundo sa pagitan ng pagpapalit ng mga trabaho. Gusto mong itanong sa'kin kung anong pinapakain sa'kin, Inay? Tirang pagkain. Naawa nga sa'kin ang katulong sa kabilang bahay kaya binigyan ako ng ulam. Kaya lang nang mahuli nila ako ay sa sahig ako pinakain. (Lee 3)

It is Suzette who gives me strength, Mother. I work like a carabao. I wake up as early as 5 o'clock in the morning. I do the laundry, cook, and iron clothes. That's nonstop work, Mother, until 1 o'clock in the morning of the following day. My only rest time are the few seconds in between work. Do you want to ask what do they feed me, Mother? Leftovers.

Kritika Kultura 35 (2020): 221-255

(c) Ateneo de Manila University

<http://journals.ateneo.edu/ojs/kk/> 
The domestic helper from the other house pities me, so she gives me viands. But when [my employers] caught me, they made me eat on the floor. (translation mine)

Noemi goes on in relating these difficulties to her mother, whom she imagines to be with her. She also reveals that most of the women in her family-from her mother to her grandmother to her aunts-are domestic helpers. While she carries a college degree in Education, poverty back home has pushed her to become a domestic helper abroad. Noemi becomes more distressed than ever when her employer's son sexually molests her, leaving her pregnant and anxious of its attendant social punishments in conservative Cairo. Her discovery of hidden letters sent to her from Manila pushes her to murder her employers. In one of the letters, she belatedly learns about the demise of her daughter.

Mga hayop sila! Mga wala silang puso! Dalawang buwan na palang patay ang anak ko'y di ko man lang nalaman! Di ko man lang nahawakan ang anak ko bago siya nalibing! Ni hindi ko man lamang naipagdasal! (Lee 17)

They are animals! They are heartless! My daughter has already been dead for two months, but I do not even know about it! I have not even held my daughter before she was buried! I have not even prayed for her! (translation mine)

Noemi suffers abroad to fulfill her own and her family's ambitions. Her labor is also not confined to her subject position abroad as a domestic worker who is made dispensable at the beck and call of her employers. Instead, it is also heavily contingent on her other social roles in the homeland. Her suffering serves as the condition of possibility for someone else's capacity to live away from penury. In this regard, suffering is not to be solely seen as a sentiment that slows down labor production and reproduction; rather, in the context of a people whose entry to migrant work hinges on a willingness to be dislocated, the act of sharing with others the unbearable burden to survive is the driving force behind Filipino domestics' crossing of uncharted landscapes as the "quintessential servants of globalization" (Parreñas, Servants 2).

This offering of skill and talent is certainly embedded within a system of regulations and expectations placed by society upon female migrant workers. Migrant women's suffering, then, is placed across the range of their subjectpositions: as daughters whose physical strength is utilized in addressing the needs of their respective families; as mothers and wives whose aspiration for a decent living and sustainable employment are easily co-opted by the unforgiving tricks of overseas trade; as women who are vulnerable to their clans' and communities' exploitation; and as Filipino nationals whose relationship with the homeland is valued in terms of the amount of remittances and balikbayan boxes they send 
year in and year out. Suffering highlights the entwined relations between migrant workers and the institutions that at once constrain and endorse these migrant workers' modes of agency. It proves to be valuable in the maintenance of one's or other people's life-worlds, insofar as it is used in addressing the problems of income and livelihood, in exploring viable lifestyle options, and in taking risks in other areas of life.

Filipina migrants have indeed come to assume an increasingly important role as overseas workers, thereby changing the overall profile of labor migration into a predominantly female one. Of the almost ten million overseas workers around the world, over 65 to 70 percent are women (Tadiar, Things 103). Feminist critic Delia Aguilar has noted that " $[\mathrm{w}]$ hile the enlistment of migrant labor has been integral to the history of capitalist development...the diasporic flow of migrant women from peripheral formations to more affluent countries is today quite unprecedented" (1). Sociologist Rhacel Parreñas further asserts that no migration flow parallels the immensity of women's labor migration from the Philippines, which constitutes the widest flow of contemporary migration today (Servants 10). A huge part of the Filipina's hyper-visibility in labor migration may be attributed to the fact that the Philippine state has put more women into the overseas labor market than any country in the world (Rosca 523-5). The Philippine state has arrogated upon itself the duty of slotting Filipino women into employments such as domestic labor, sex work, nursing, factory work in garment and electronic industries, among other jobs normatively deemed feminine (Tolentino 422). Studies on female migration employ terms such as "sexual economy," "libidinal economy," and "vaginal economy" to account for women's crucial role in labor migration and to make Filipinas central to commercial ecologies of the Philippine nation-state and its international partners.

That domestic labor predominantly assumes a female countenance and that it is enacted within the trappings of the family and the state affirms the disciplinary and enabling orientations of society regarding women's suffering. If the production of suffering is largely driven by social institutions that transcribe on the bodies of female migrant subjects this experiential or existential challenge of pain in order to prop up social communities and retrieve them from potential or present perdition, women conversely take on the pain to secure both the "meaningfulness of a particular pattern of life" (Clifford Geertz, qtd. in Das, "Suffering, Theodicies, Disciplinary Practices" 564) and the legitimacy of roles within and beyond the confines of their homes, which are threatened to disintegrate in the face of lingering poverty or unspeakable loss. That women exteriorize this capacity to suffer and to allay the suffering of others-an embodied experience that cultural studies scholar Neferti X. M. Tadiar encapsulates in the Tagalog lexeme mapagmalasakit ("Noranian Imaginary" 76)-speaks volumes how these feminized passions and 

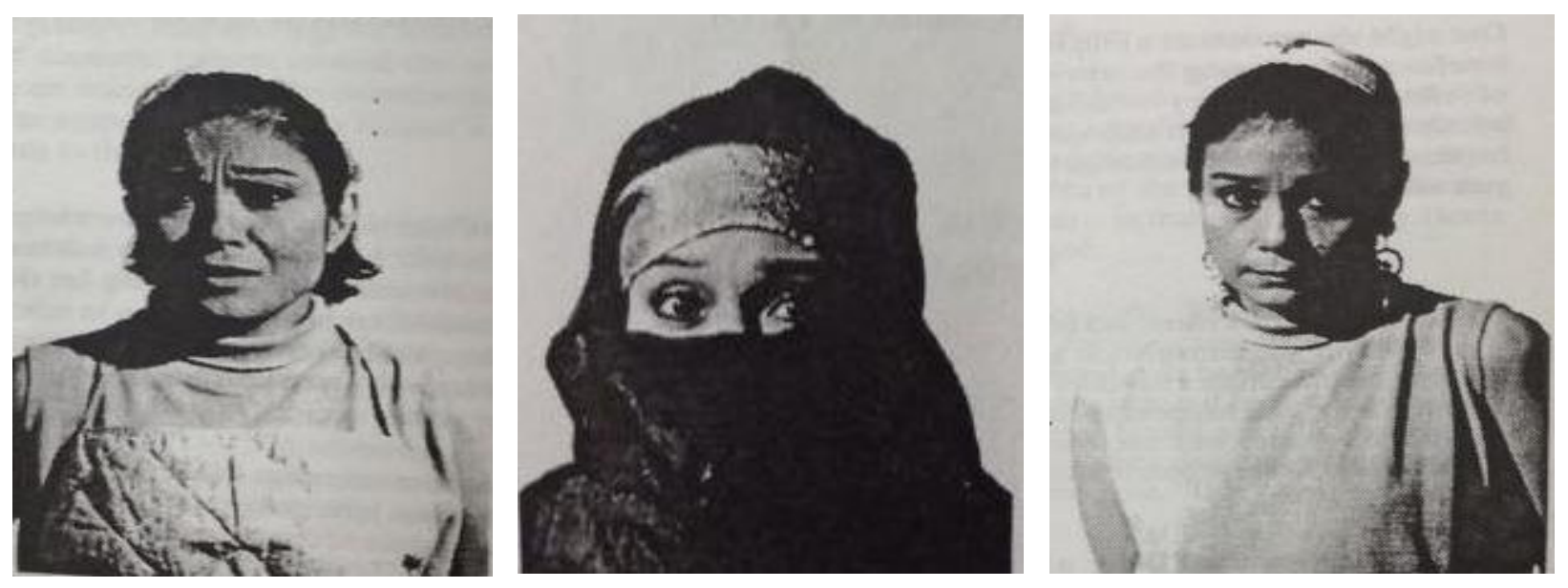

Fig. 5. Aunor plays Fe, Noemi, and Dolor, all domestic helpers suffering in the diaspora for their families back home. Photo courtesy of the PETA Library and Archives.

compassions dually exist for the subject-in-pain and the other subjects who are saved from dissolution.

This suffering magnifies the operation of global capitalism in relation to gendered and sexualized migrant workers: it pushes them outside the home and at the same time reaffirms the belief that they belong inside the home (Parreñas, Force 4). It also hints at a break in the conventional division of labor in the Philippines that defines men as the haligi ng tahanan (pillar of the home)/the breadwinner and women as the ilaw ng tahanan (light of the home)/homemaker (Force 4). What this signifies is that the physical female body is activated by migrant workers in other contexts of living, with full awareness of a life that must be lived in rupture and loss, in order to transform a world in which one may dwell again (Das, "Language and Body" 68-69). It is in this sense that female migrant labor and suffering operate as necessary logics in the reproduction of certain societal systems, which convert "the personal pain of an isolated consciousness" ("Language and Body" 68-69) into something that is publicly and collectively created, shared, and consumed. It is also in this regard that women exemplify the ways they are molded as domestic bodies and moral citizens of the nation, on the one hand, and reveal the malignancy of their subject-positions in society's projects of modernity and progress, on the other. Fe, the domestic helper in Hong Kong, is a pertinent example because her participation in sex work, an informal job in which most of her friends are involved, is deeply propelled by an inescapable responsibility to pay her family's bills, her sister's tuition, and her father's loans. 
Inasmuch as the zones of domestic labor to which Noemi, Fe, Dolor, and Loida belong signify realities of oppression, prostitution, family separation, and deception, they carry and engender different sorts of violence against women who are cast as "bioterritorial resources of the nation" and as modern-day slaves of countries across the world (Tadiar, Things 104-105). Literary and cultural critic Epifanio San Juan, Jr. asserts that due to the incongruities, non-synchronies, and shifting subjectpositions of the non-Western "Other" within so-called "free markets economies" and "liminal spaces of subjugated territories," overseas Filipino women workers may find the "spaces of their body, home, community, and nation" severely disjointed if not totally annihilated (16). In these social contacts and contracts within a sexualized and gendered division of labor, the dispersion of Filipino women across the world is accompanied by the brutal disintegration of their lives or perhaps the "slow death" of their humanity. PETA affiliate, R.B. Andres, exemplifies through the following passage the kind of disjointedness in mind, affect, body, will, and spirit that migrant female workers suffer abroad.

Sa kabuuan, ang dula ay di lamang sa kung paano nakaka-survive ang mga manggagawang Pilipina sa ibang lupain, kundi hinggil din sa kung paano nila pinananatiling buo ang kanilang katawan, damdamin at kaluluwa habang pinagsumikapan nilang buhayin ang kanilang pamilya sa Pilipinas habang nagtratrabaho sa ibang bansa. Malungkot ang pakiramdam na iwan ang sariling pamilya at bayan ngunit mas nakapanlulumo ang mawalan ng kaluluwa sa banyagang lupain.

On the whole, the play is not only about how Filipino female workers survive in other countries, but also about how they keep their bodies, their feelings, and souls intact even as they strive to fend for their families in the Philippines while being overseas. It is a sad feeling to leave one's own family and nation, but it is even more weakening to lose your soul in foreign lands. (Translation and emphasis mine)

Andres's focus on the loss of kaluluwa or the human soul as the strongest blow against the Filipino overseas worker's humanity is particularly instructive in understanding the nadir into which the Philippine nation and its human fragments have descended at a most critical time of global migrations and labor exportations. The centrality of the notion of kaluluwa in Philippine national discourse has been discussed by cultural historian Resil Mojares in his essay, "The Haunting of the Filipino Writer." Tracing this "deeply rooted idea" and "power-laden word" to Malay and Indigenous Filipino cultures, Mojares writes that the prevalence of the soul can be sensed through its various terms (i.e., the Malay semangat, the Bisayan kalag, the Iloko Kararuwa, etc.) across and beyond the Philippine archipelago (299). These terms confirm the fundamental idea of the soul as "the élan vital, [the] principle of fertility and potency, [and the] sign of what is whole and fulfilled" (299). In terms of its relation to the physical body, the unformed, infirm, or lost soul signifies a weak 
and collapsing corporeality. Soullessness, therefore, "is the condition of being outof-sorts portentous of a lack or loss (but also, we must add, the stirring of a coming vision, the onset of something dangerous, strange, and new)" (299). Mojares adds that the "Filipino Soul," or Alma Filipina, was seen by Filipino writers not only as an edifying sign of "a people's dream of selfhood, autonomy, and freedom" but also as a reverent invocation of the People and the Nation (298). In these explanations about the soul or kaluluwa's connections to the individual human body and the collective social body, Mojares argues that what sickens people may be translated to the afflictions of communities, "nations," and the body politic.

This essay suggests that the Philippines remains an "aborted nation," a "drifting soul," and an "archipelago in exile" precisely because the very strands of its dear life are heavily constituted by a massive number of people who evacuate or are presently outside of their local or national communities to suffer, be enslaved, or carve out alternative and more gratifying realities elsewhere. As the women in $D H$ evidently show, this tension-filled relocation from the Philippine nation to foreign spaces causes multiple fragmentations of body (katawan), mind (kaisipan), and spirit (kaluluwa). The figures of Noemi, Fe, and Dolor are cast as docile (house helpers), tabooed (prostitutes), and neglectful (mothers), especially when they enter networks of overseas labor where they encounter various defilements of all fibers of their flesh. If these women characters' desolation in, and dependence on, migrant domestic work serve as gauges in examining the national status of the Philippines, then the nation's soul is neither temporarily lost nor certainly capable of finding its way back to healing, as Mojares claims (303). "[T] aken away to a secret place" such as countries in Asia, Europe, and North America, the nation's soul, like the women characters of $D H$, finds it difficult, if not close to impossible, to escape its diasporic reality and to heed calls that lure it to "come back, come back" (303). In an age that sees the mass exodus of the Filipino people from their home country, the kaluluwa of the Philippine nation, like the kaluluwa of $D H$ 's women, is battered and dispirited, starved and unwell.

However, despite the multiple destructions that their body and soul confront in the intertwined oppressions of being desperately ensnared in alien countries and forcibly disaggregated from the national sphere, figures of Noemi, Fe, Dolor, and Loida remain instructive in the different ways they hold themselves up as both witnesses to, and participants in, political economies and social milieus that generate from and inscribe on these women characters varying modes of bodily and spiritual suffering. Despite their disjointedness, debasement, and dislocation, the domestic workers in $D H$ continue to give up parts of their humanity for the continuation of the life-worlds of Other entities to which their Selves remain emotionally, culturally, and biologically related but also physically and geographically dissociated: the Filipino family and the Philippine nation. 
Involving a conjunction between the Self and the familial Other, suffering is related to sacrifice, or the act of surrendering something valued or valuable for the sake of something considered to have a higher currency or a more pressing claim. To sacrifice and be sacrificed, then, means to participate in a salvific diasporic dispensation in which laboring migrants remain hopeful, even in the face of danger and despair, of being led to a path of progress. Surely there is a strain of agency at work in this inclusion of bodies in national and global systems of dispersal to the extent that migrants may arrogate upon themselves a practical redressive action to the economic quandaries that weigh them down. There, too, is a glimmer of hope in this recourse to a temporary exodus from the homeland to the degree that it affords migrant workers an occasion in which they may activate their capacity to aspire for the realization of their dreams.

This essay further argues that submission of migrants to difficult circumstances to spare others from their burden evokes an encounter with the intimate insofar as the migrant who sacrifices finds herself/himself and perhaps her/his loved ones close to what is aspired. Whether out of desperate necessity or personal desire, this willingness to bargain oneself for others is an intimate risk within a "passional (as in Christ's passion) economy" (Flores, "Colonial Posterities" 25) on the part of the sufferer. Like the writer whom Mojares describes as most prolific and effective in its confrontation of the soul's absence or its acknowledgement of the shocks, seductions, and sins that affect the soul, the people, and the nation (311), migrant workers may likewise be considered in their strongest and most dynamic state when they recognize their potent ability to mobilize their own and other people's lives in spite or because of their destitution. Perhaps, going abroad may be a recognition of possibilities of a better life that lies ahead. Just like the soul that accesses its potency from the outside (labas), "as represented by those moments when the soul departs from the body and roams the countries of dream (even nightmare)" (Mojares 309), Filipino women may also perhaps derive strength from their life experiences of pangingibang-bayan or changing countries and pagsasakripisyo or sacrificing. Such courage from migrant workers to leave their native shores and be unconfined to local or national affiliations may perhaps connote not only a willingness to be further honed by other worlds, other people, and other modes of living but also an openness to be filled "with visions of strange things seen [elsewhere], and an even richer sense of ... identity and difference" (309).

Unfortunately, $D H$ provides a full serving of suffering without offering a clear view of how human beings may realize their agency amidst demeaning social structures of labor migration. In Lee's play-within-a-play dramatic narrative, particularly in the "staged" reality that it enacts, sufferers are weighed down by the constant reversals of fortune. These women are robbed of opportunities to rage against situations that physically or symbolically wound them. They languish or fall 
apart in the face of a looming destruction. To Dolor, being a domestic contributes to the disintegration of her own family in the Philippines. To Fe, working in Hong Kong draws her to the physically dangerous market of sex work. And to Noemi, toiling hard in a libidinal and racialized household defiles her womanhood and humanity. In one of her failed attempts to escape the household of her employer, Noemi reveals:

Isang araw ay gusto na naman akong pagsamantalahan ng anak ng amo ko. Kaya nagtangka na akong tumakas. Pero nahuli ako ni Madam. Napilitan akong sabihin ang totoo. Nagalit siya at tinapunan ako ng kumukulong tsaa. Sinipa ako sa tiyan at pinagsasampal. Naiinsulto daw siya na pinatulan ako ng anak niya. (Pipilitin ang huwag umiyak.) Mula noon ay ikinukulong na nila ako dito sa loob ng bahay. Bawal daw kasi ako magsumbong sa Embassy. Kapag nasa labas sila ng bahay ay ikinakandado nila lahat ng bintana at pinto. Ma'am, gusto kong itanong, paano kung magkasunog? (Lee 16)

One time, the son of my employer wanted to rape me. That is why I attempted to escape. But Madam caught me. I was forced to say the truth. She got mad and poured boiling hot tea on me. She kicked me in the stomach area and spanked me. She felt insulted that her son took interest in me. (Forces herself not to cry). Since then, they would lock me up inside the house. I was not allowed to inform the Embassy. When they are outside the house, they would close all windows and doors. Ma'am, I wanted to ask, what if there's fire? (translation mine)

Like Noemi, many domestic helpers are reduced to "units of labor, living resources, vectors of capital flows, or isolated body parts" (Pratt xix-xx) for their employers, their families, and certainly for the nation-states that source them out. In the appropriation of women as low-wage workers in gender-typed and gendersegregated jobs, female workers are not only emplaced in patriarchal, heterosexist, and capitalist-driven channels of livelihood and labor fixing women's natural dispositions and genetic constitution to a certain range of unskilled work (Tadiar, Things 103). Rather, they, too, are positioned in conditions where they may be condemned to a living/lived reality of potential cruelty and death. This feminization of labor indeed comes with layers of victimization, from battery to harassment to sex trafficking to detention to murder, all of which naturalize violence particularly against Filipino women. From this view, every act of migration, therefore, becomes a contact with subjugation and a participation in an export economy that depends on the nonstop cycle and permutation of marginalizaton. Domestics Noemi, Fe, and Dolor are figures with almost erased agentive acts in the presence of the horrifying abuses. These women are almost figures of passivity, failure, and fatalism.

In this regard, $D H$ lays bare a transfiguration of Julia Kristeva's abject figure in the Filipino migrant worker whose ejection from the Philippines and inclusion 


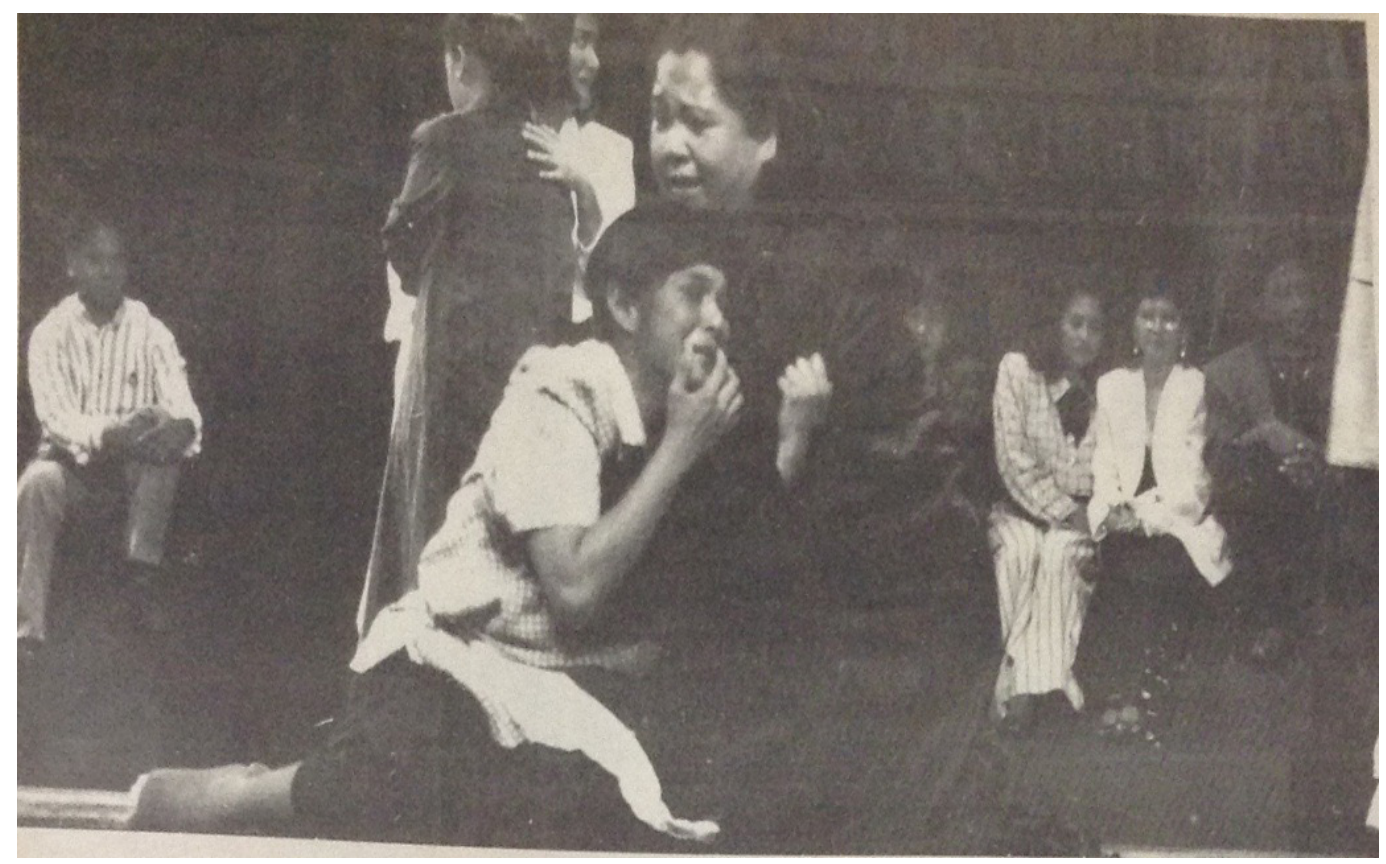

Fig. 6. A scene from the play shows Aunor, who plays a domestic helper, crying to a fellow actor. The stage arrangement of the cast shows the Brechtian mode of theater making. Photo courtesy of the PETA Library and Archives.

in the diaspora are easily co-opted by state rhetoric and structures of capitalism. However, if the abject is "the anterior to the distinction between subject and object in normative language" (Kristeva 376), then Filipina migrant workers partially qualify as abject figures even if their productive capacity and visibility in society also nuance the very tenets of this discursive term. While it is true that most migrant workers, as $D H$ generally illustrates, are derided as second or third class citizens in foreign lands and thus demeaned as commodities for exploitation and purchase, they however do not and cannot devolve into a total abject figure which "culture ... must purge, separate, and banish" (376). The eviction of migrant workers in the web of global labor and capital is a fragile, if not an untenable project insofar as the very presence of OFWs composes the course and operation of the forces that want to dominate or even eradicate them. Writing about the social reproduction that Filipina workers facilitate in national, regional, and global spheres, San Juan states that "the Filipina domestic is what enables European/North American bourgeois society and, by extension, the relatively prosperous societies of the Middle East and Asia, to reproduce themselves within their nation-state domains and thus sustain capital accumulation with its horrendous consequences" (15). 
This essay argues that even if the reigning regimes of power in the diaspora constantly attempt to diminish the agentive voices and bodies of migrant workers, total subjection of these women is not possible and will never happen. If there is truth to the Derridean dictum on the dissimulation of central power, or the instability of what are falsely believed as totalizing structures (46-47), then members of society will find ways to circumvent the systems of existing superstructures, perhaps within and through the transactions initiated in everyday life. For example, the hilarious and adventurous Fe embodies potential subversion in her situation as a DH turned sex worker in Hong Kong. Unlike Noemi and Dolor, Fe has relatively kept her zest for life and remains in "control" of her body, despite the cruel encounters she has had in the past. She says: "Di ako nagtatagal sa mga amo ko dito. Palit ako nang palit. Ang tawag nila dito sa palit nang palit ng amo, nag-e-aerobics. Ako kasi pag ayaw ko na, layas. Di ako nagpapaapi" [I do not stay long in all my masters' employ here. I keep changing. Here they call someone who keeps changing her employment, doing aerobics. When I personally do not like my work anymore, I leave. I do not allow others to oppress me] (translation mine). The scene involving migrant workers, Ester and Delia, and the play's director, Agnes-all part of the "real frame" of $\mathrm{DH}$-further illustrates the ability of Filipinos to make sense of the value of their lives abroad:

Agnes: (sa audience) Dati mga mayayamang Español lang ang nakakayanang magkaroon ng DH. Ngayon pati middle class na. Lahat ng mga trabahong mabababa at di nila masikmurang gawin ay ipinapasa nila sa maid. Ang tawag nila dito sa maid ay Filipina. At bibilib ka sa Pinay. Maski anong sitwasyon mo isabak ay nakaka-adapt siya. Para talaga siyang citizen of the world, naglalakbay sa buong daigdig, sinasakop ang buong mundo. Kaya walang identity.

Delia: Bakit, ang Europa ba ay magiging Europa kung hindi sa ating mga Pilipina? Aasenso ba sila kung hindi sa atin? Sino ang mag-aalaga sa kanilang mga anak? Sino ang magluluto ng kanilang mga hapunan? Sino ang maglilinis ng kanilang mga dumi? (saka pupunta sa tabi at kukuha ng retrato)

Agnes: Gusto nila ang mga Pilipina dahil mapagkakatiwalaan. Walang nawawala sa bahay. At masisipag.

Ester: Sa Pilipinas pa lang kasi ay trained na tayo para maging mahuhusay na domestic helpers at nang masiyahan sa atin ang mga foreigners. May kakilala nga ako, ang anak ang sipag-sipag mag-aral mag-Ingles, kasi daw gustong paglaki'y maging domestic helper sa Italy!

Agnes: Pero maski asensado'y may mali pa rin kung kinakailangan pang umalis ng sariling bayan ang isang tao para lang may makain ang pamilya niya.

Agnes: Before, only the rich Spanish people could afford to have a DH. Now, even the middle class can. All the menial and undesirable work they pass on to 
the maid. They call the maids here Filipina. And you would be amazed with a Pinay. Whatever situation you field her to she can adapt. She truly seems like a citizen of the world, travelling around the world, conquering the entire world. That's why she does not have an identity.

Delia: Why, would Europe be Europe if it were not for us Filipinas? Would there be progress if it were not for us? Who would take care of their children? Who would cook their supper? Who would clean their dirt?

Agnes: They like Filipinas because we are trustworthy. Nothing gets lost at home. And hardworking.

Ester: In the Philippines we are already trained to be good domestic helpers to please foreigners. In fact, I know of someone whose kid studies English very conscientiously, because she wants to be a domestic helper in Italy when she grows up.

Agnes: But even if one's successful, there's still something problematic when one needs to leave the country just to feed one's family. (Lee, translation mine)

These comments articulate a sense of self-reflexivity among migrant workers who can make sense of their life and labor conditions abroad. While $D H$ presents a smorgasbord of trauma stories that undermine the will of migrant workers, some instances in the play show mindful domestics who are critically conscious of their subject positions in the dehumanizing diaspora. Unlike Noemi, Fe, and Dolor who cannot liberate themselves or who cannot be liberated by others from the trenches of disenfranchisement, the characters of Ester, Delia, and Agnes outside "the staged" reality can, by contrast, recast their suffering and rethink strategies that may even temporarily ease up their burden. Unlike the first group of women who are trapped in peonage, the other group rises above the situation to "assert agency and reclaim destiny" even just by a discernment of their complicity with the operations of global migration (Flores, Star 85).

This essay's second section argues that despite the lack of power, the extreme pain, and the lingering longing that constitute $D H$ 's characters, there remains an opportunity to imagine experiences of suffering and sacrifice as part of a future where grief gives way to peace, destitution to relief, and marginalization to progress. This does not mean that suffering or pain departs the realm of the personal. Rather, it only opens this personal experience of suffering to the social world (Kleinman, Das, and Lock xix), so that the very person who suffers or mourns would not be helplessly "condemned to dwell alone and nameless in the ruins of memory" (Das, "Language and Body" 69). This essay further asserts that the conversion of migrant suffering and sacrifice to critical, productive, and even transformative energies may fruitfully happen through performances that deconstruct and reconfigure narratives, representations, bodies, and modes of theater making. 


\section{PERFORMING MIGRATION}

This section examines how performance in $D H$ raises socio-political consciousness about migration and registers new communal relations among the play's migrant characters. Lee's Brechtian play-within-a-play technique disturbs the illusion of reality and exposes accordingly the construction of that reality in theatrical terms. As appropriated in $D H$, the Brechtian mode disrupts theater's suspension of disbelief "whenever the thread comes too close to the spinal conflict-elegantly resolved but never settled. Whenever sympathy is too close, [members of the audience] are pushed back and reminded that this is merely a rehearsal-an amateur theater group of domestic helpers who want to portray their life-stories via the dramatic arts" (Viernes n.p.).

Thus formulated, the three-plays-within-a-play technique allows an intersection of the "worlds" between migrant workers who are troubled by their placement in foreign spaces, as in the case of Noemi, Fe, and Dolor, and those who can actually speak about and act on their suffering, as in the case of Loida and the rest of the characters in $D H$. This strategy is used to render performance, as well as the rehearsal that this performance entails from migrant workers in $D H$, as "contact zones" where hierarchies are reassessed, domestic work is rethought, and personal predicaments on migration are uncovered, named, and threshed out.

Transitions from "reality" to the "staging" of this reality function as interstitial instances whereby ideological interventions, mostly in the form of verbal utterances, are overtly embodied and enunciated by characters on stage. The scenes where Loida and the cast, for example, pull out their costumes to go back to their "real" lives are also the same instances when everyone deals with the core problematique of their performance: why do they even need to put up a play on domestic helpers and make a spectacle out of their fellow overseas workers' stories of anguish? These are also the very moments that issues in their migrant community, like the undocumented status of their fellow Filipino worker Ophelia who is in hiding from immigration authorities, are discussed amongst themselves. In these scenes, the characters boldly question policies on migrant or immigrant acts, interrogate creative techniques in production, or even tease out personal choices made by members of the Filipino community in Italy.

For example, whenever Loida takes a break from her roles as Noemi, Fe, and Dolor, she consistently tells the group and their director Agnes about her reluctance to accept the central role originally assigned to Ophelia. Apart from her intention to leave Italy for the Philippines before Christmastime, Loida also initially expresses her disbelief in the hopelessness of Noemi's character. She says: "I agree. Noemi's story seems too dark. Why should murder be the solution to her problems?" (Lee 24, 


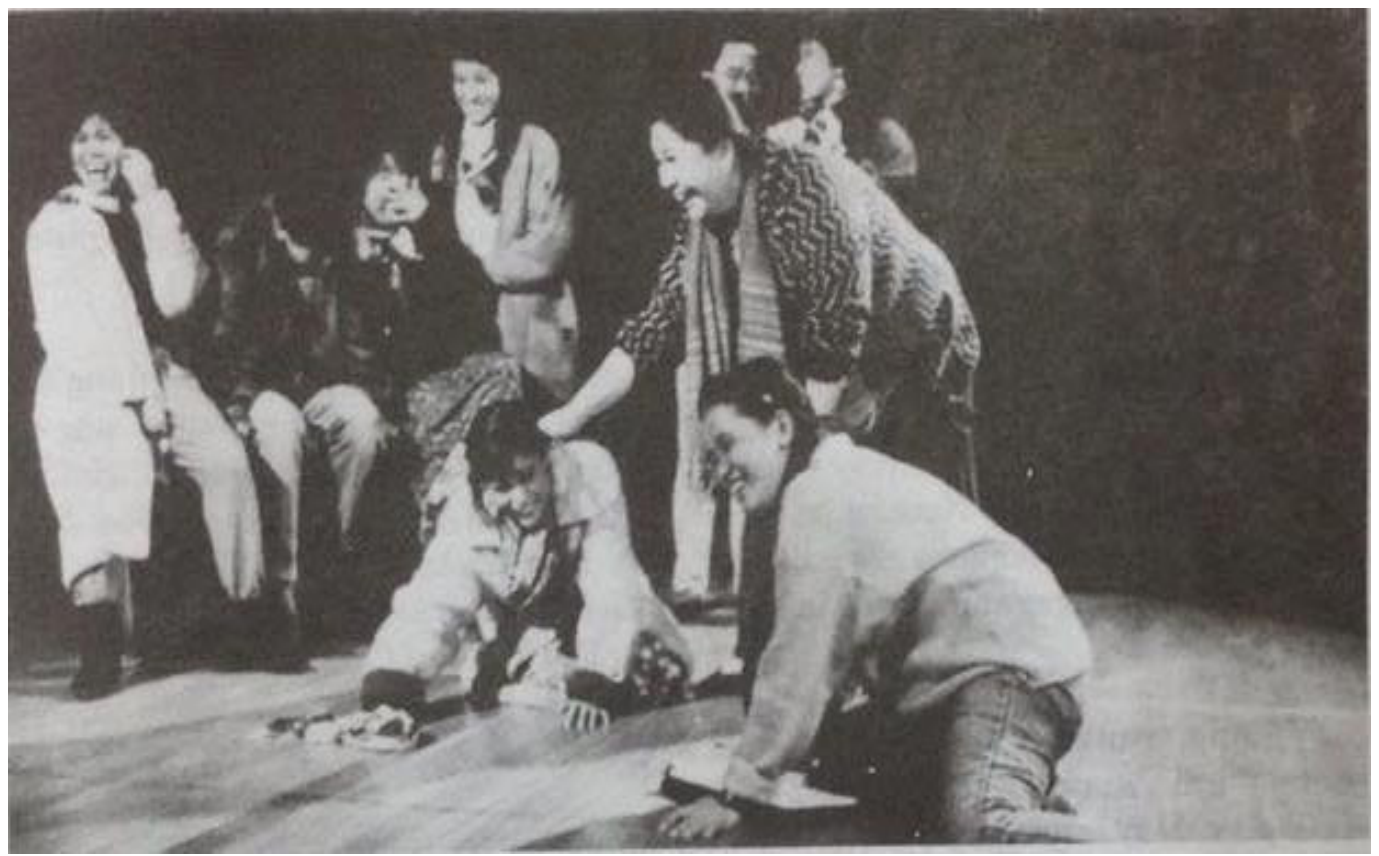

Fig. 7. Some members of the cast of DH are shown enjoying one another's company during their stage rehearsal. Photo courtesy of the PETA Library and Archives.

translation from the Tagalog mine). Loida hesitates to perpetuate stereotypes and interrogates a common image that tries to capture a "domestic helper experience." This hesitation is supported by Loida's fellow actor and laborer Reggie:

Reggie: (kay Agnes)Baka dapat maghanap tayo ng ibang materyal. Iyong mas masaya kaysa sa kuwento ni Noemi. Kawawa naman ang bayan natin. Lagi na lang Pilipinang biktima at desperado ang nakikita sa atin. Baka isipin tuloy ng iba, ang mga Pilipina sa abroad, mamamatay-tao. Baka lalong matakot ang mga foreigners na i-hire tayo. (Lee 24)

Reggie: (to Agnes) Maybe we need to look for another material. One that is happier than Noemi's story. Our country is pitiful. It's always a victimized and desperate Filipina that we see. Others might think that Filipinas abroad are killers. Foreigners might be more afraid to hire us. (translation mine)

Performance is a means to self-identification and self-information, or a method to access and parse what is normally unobvious. Something is potentially productive in foregrounding a common experience among domestic workers, through acts that prompt and provoke the emergence and development of a certain disposition toward 
issues. Indeed, there is agency at work in this gesture of wanting to demonstrate the precarious lives of OFWs to the degree that performance warrants speech about, and scrutiny of, issues and figures represented on stage. In the "performed" frame where Noemi, Fe, and Dolor appear, they are rendered insignificant by their exploitative conditions. In the "real" frame of Loida and company, they are opinionated and reflective, determined and surviving. Although placed in two different frames, these characters are not detached from each other; instead, they all fall within and contribute to an "ethos of labor migration" (Guevarra 4) insofar as they embody and are enacted by migrant relations, practices, and logics.

Whereas Loida remains indecisive in accepting the lead role, despite the assurances of fellow actors of her effective portrayal of this assignment, the director Agnes consistently dissuades the domestic helper from backing out. When Loida finally concedes to take on the task, she is also informed that for the final performance, the stories of Noemi, Fe, and Dolor will be strung together so as to present the many interconnected issues that migrant workers collectively confront. This suggestion is telling of a goal to create a representation of solidarity among DHs across the world. This coming together of experiences in and through a performance dismantles any actual or imagined barrier among the play's characters. There is an affective tendency in a desire to visualize and make possible a critical mass of Filipino migrant DHs which may also unite with one another on the basis of their diasporic subject-positions.

Indeed, performance serves a significant role in the collective and personal transformation of migrant communities in $\mathrm{DH}$. In her introduction to Performance and Cultural Politics, performance studies scholar Elin Diamond writes that the category of performance "describes certain embodied acts, in specific sites, witnessed by others (and/or watching) self" (1). It further involves cultural stories, traditions, and political contestations in time and space. However, performance alone cannot stand as a radical gesture. That is, it cannot reflectively place appearances and stereotypes under suspicion, expose the artificiality of original claims of authorities, and articulate multiple voices that parody or interrogate hegemonic discourses. As performance studies scholar Dwight Conquergood and social theorist Moya Lloyd claim, performance does not carry any inherent power to subvert and transgress ruling systems of power. They further write that performance may only garner potency the moment it is seen from the critical viewpoint of performativity, which allows the former category to dismantle, though not totally disregard, empires of dominant practices. It is the notion of performativity, Diamond further notes, that "creates the terminology of 're' in discussions of performance, as in reembody, reinscribe, reconfigure, resignify. 'Re' acknowledges the pre-existing discursive field, the repetition-and the desire to repeat-with the performative present, while 'embody', 'configure,' 'inscribe,' 
'signify', assert the possibility of materializing something that exceeds our knowledge, that alters the shape of sites and imagines other as yet unsuspected modes of being" (1). The relay from performance to performativity makes possible the imitation, exaggeration, and more importantly re-signification not of selfcreated or self-enacted codifiers and signifiers, but a set of socially constellated ones that at once follow and exceed certain bounded patterns (Lloyd 202). Gender studies scholar Judith Butler, for her part, argues that it is in the re-enactment and re-experiencing of a set of meanings that are already established where subversion and transgression may be located (526). Through their performative manners under excitable conditions and their transformation within performativity, performances carry the possibilities of subversion: what is recited/reified is the same subject/object that gets re-mastered/revised.

In other words, while performances become the means by which social categories, for example, may be reified in the staging and reconstitution of experiences, performativiy at once emphasizes, reveals, and revises social over-determinations, such as historical conventions, perceived essences, and conditions of oppressions. Through performativity's "stylized repetition of acts," the artificiality of facticity, the materiality of things, and the inconsistencies of procedures are made explicit. In this regard, whereas performances may also elide certain issues, it is performativity that "crashes and breaks through sedimented meanings and normative traditions and plunges us into the vortices of political struggle" (Bhabha, qtd. in Conquergood $32)$.

Thus conceived, the stage play of the domestic helpers is a site in which reiteration and revaluation of migrant experiences happen. In the stage production where Loida takes on the parts of Noemi, Fe, and Dolor, all the characters drift between past and present, presence and absence, consciousness and memory. These performances are means for domestic helpers to metamorphose into at once selfaware and resisting laboring subjects, even as they also operate as sites of rehearsal and staging where migratory lives move from mere sources of emotions to active agents of embodied practices. Furthermore, these performances transform these domestic helpers into agentive migrant subjects - that is, persons who, despite or because of being caught in indeterminate modes of living and laboring, remain capable of discussing, revising, and acting upon the complex narratives of power subjugating or engendering them. These progressions in performance expose how migrants act as subjects of history not characterized by hollow desires for itinerancies, nor totally enacted upon by institutional dicta or policies.

Performance then serves as an opportunity whereby the subjectivity of domestic workers like Loida, Dolor, Fe, and Noemi materializes as a local and universal image of return and redemption, suffering and servility. The constitution of these migrant 
workers' diasporic or transnational subjectivities is remembered, realized, and revised in and through a performance or a performative effort that exposes trauma and loss as wounding experiences that may instigate personal realizations and political mobilizations from the involved migrant domestic helpers. Andres points out the function of performance in $D H$ when he states: "Sa proseso ng pagganap sa iba't ibang roles para sa dula, maitatampok nila ang iba't ibang karanasan at kamalayan ng iba't ibang uri ng mga Pilipinang manggagawang migrante sa lahat ng dako ng daigdig - mula sa mga domestic helpers hanggang sa cultural entertainers hanggang sa mga health at hotel workers" [In the process of playing different roles in the play, they will showcase different experiences and consciousness of different kinds of Filipino female migrant workers from all parts of the world-from domestic helpers to cultural entertainers to health and hotel workers].

In $D H$, it is in performance where Loida discloses the reason behind her hesitation to assume the roles of Noemi, Fe, and Dolor. It is during their group rehearsal that Loida confesses betraying Ophelia and her migrant community. The ordeal of Ophelia, the supposed lead star of the production whom Loida replaces, is caused by the latter's jealousy. Loida deceives everyone in exchange for money. In an overdramatic scene, she pleads guilty:

Loida: (Habang patuloy na nagsasalita ay sinisira ang costume niya, tinatanggal ang wig niya at make-up). Ang kasalanan ko'y walang kapatawaran. Hindi lang si Ofelia ang sinuplong ko sa mga pulis. Marami pang ibang mga kababayan natin. Nagpapabayad ako! Naiinggit kasi ako sa kanila. Ako'y walang pinagaralan. Lahat sila'y nakapag-aral. At nakakuha agad ng magagandang trabaho. Maski si Ofelia na illegal. Ako, nagpakahirap akong maging legal. Bawat bagay na nakuha ko sa buhay ko ay pinaghirapan ko, pinuhunanan ko ng dugo. Pero si Ofelia, at ang iba pang mga katulad niya, lahat ay napakadali para sa kanila! Patawarin mo ako, Ofelia, wala akong inisip kundi ang sarili ko! Ayoko kasing umuwi nang walang pera! Maraming umaasa sa akin sa Pilipinas! Mapapahiya ang pamilya ko! May ipinapatayo kaming bahay! Ipinagmamalaki ako ng mga magulang ko sa aming baryo! Pero mali ako, mali ako!

Lalapit sa audience.

Loida: Patawarin n'yo ako! Dapat akong isumpa! Nasa mga kamay ko ang dugo ng mga kababayan natin! Nakalimutan kong isa rin akong Pilipinong kagaya n'yo! 
Loida: (While continuously talking she is ripping apart her costume. She is removing her wig and make up.) My sin is unforgivable. It is not only Ofelia whom I reported to the police. A lot of our fellowmen. I accept bribes. I envy them. I am uneducated. All of them are. They easily got good jobs. Even Ofelia whose status was illegal. I worked hard to have a legal status. Everything I got in life I worked hard for, I invested in with blood. But Ofelia, and others like her, everything was easy for them! Forgive me, Ofelia, I didn't think of anyone but myself! I do not want to go home penniless! A lot of people depend on me in the Philippines! My family will be embarrassed! We are constructing a house! My parents boast about me in our barrio! But I was wrong, I was wrong!

Approaches the audience.

Loida: Forgive me! You must curse me! My hands are stained with our fellowmen's blood. I forgot I am also a Filipino like all of you! (translation mine)

This twist in $\mathrm{DH}$ leads to a tensioned exchange between Loida and her coperformers. There is no closure to this theatrical production however; instead, everything grinds to a halt, leaving the play open-ended and faithful to its Brechtian framework. In this kind of ending, it is neither Loida nor any of the three female workers from Cairo, Hong Kong, and Barcelona who give the final word or perform the conclusive act. It is Nora Aunor, the star of the overall production and the main invitation to this theater, who sheds off the theatrical illusion and takes back the limelight to offer a personal pronouncement to the audience whom she encourages to become active participants in resolving the play's conflicts. This final turn in PETA's project does not only magnify $D H$ 's most scathing propagandistic critique, but also emphasizes how PETA strategically banks on Aunor as the anointed person of the theater who can radically enunciate a nationalist ideology on behalf of migrant workers dispersed across the globe.

\section{MELODRAMA OF MIGRATION}

This final section deploys the term "melodrama of migration" to discuss the spectacularization of laboring women overseas. To link melodrama to migration is to take out the aesthetic mode from its traditional confinement in the nation-space, as well as to situate its characteristic domestic ideology, excess, and emotionality in a theater industry that taps these traditional elements to realize a nationalist vision. Thus, the term "melodrama of migration" intertwines the aesthetic and the political within a national theater group such as PETA and through an iconic actress known 
for her controversial involvements in issues of society. In this regard, to constellate an aesthetic mode of a genre, a social phenomenon, an artistic institution, and a celebrity is to analyze the inter-subjective field that composes, and is composed by, a theater that reproduces overseas contractual work/workers on stage through the talent of a revered actress who gathers into her fold immense devotional followings.

While Aunor's essaying of the melodrama of migration runs the risk of seeing $D H$ falling into the trap of a star system that seeks to deglamorize idols of the cinema by lending them to nationalist projects largely for the sake of holding up commercial interests and the waning popularity of stars, the Superstar easily takes exception in the manner by which she maneuvers her way around the showbiz industry. Unlike other celebrities of her status who portray members of the lower class without committing themselves to the ideological cause or to the (re)presented subjects in their respective projects or films, Aunor lends her stellar performance and illustrious persona to PETA's $D H$ not to glamorize the social realities of domestic helpers. On the contrary, she questions national authorities and therefore initiates creative or social trajectories that can hopefully transform the theater, the audience, and society. Whereas other actors portraying OFW roles would not imagine themselves deviating from the limiting confines of the melodramatic mode, or transgressing film companies' preferences for sanitized endings that eventually neutralize cinematic expositions of exploitation, Aunor in $D H$ weighs in on the issue of migration, as well as embodies the discourse of suffering even after the play's staging. The "cinematic legend on stage" daringly launches tirades against the Philippine government and other social institutions like the Filipino family, which are the purported major reasons behind the lives of suffering migrant workers:

Walang ending ang aming dula. Tumakbo muli ang buhay ng mga characters na nakilala niyo kanina. May masaya, malungkot, pero lahat ay umaasa. Pag-uwi ko sa bahay, pagkatapos ng palabas na ito ay hindi ko makalimutan si Loida, Noemi, Fe, Dolor at iba pang domestic helpers na nakilala ko.

Pag naiisip ko sila, nagagalit ako sa mga mahal nila sa buhay na hindi nagpapahalaga sa kanilang paghihirap, sa mga manloloko nilang recruiters, sa mga mapang-api nilang employers.

Galit na galit din ako sa gobyernong ito na parang walang ginagawa sa kanilang mga karaingan.

Gusto ko sanang bumalik silang lahat at dito magtrabaho, kapiling ang kanilang mga mahal sa buhay. Pero may solusyon ba tayo sa kanilang kahirapan.

Masakit isipin na walang ending ang istoryang naririnig natin tungkol sa mga migrant workers.

Kaya ako bilang artista, bilang si Nora Aunor sampu ng mga kasama ko sa dulang ito ay patuloy na magkukukwento tungkol sa buhay nila. 
Hangga't sila'y naapi, hangga't nagbibingihan ang kinauukulan, hanggang sa dumating ang panahon na lahat ng mga DH saan mang lugar sa buong mundo ay makabalik na sa Pilipinas at nang mayakap at makapiling ang kanilang mga mahal sa buhay.

Para magkaroon na rin ng magandang wakas ang kanilang kuwento.

There is no ending to our play. The lives of the characters you all met a while ago just went on. There are those who are happy, sad, but all are hopeful. When I leave for home after this show, I will not forget Loida, Noemi, Fe, Dolor and other domestic helpers whom I met.

When I think of them, I get mad at their loved ones who do not value their hardships, at their scrupulous recruiters, at their oppressive employers.

I am extremely mad at our government that seems unresponsive to their grievances.

I wish to see them come home here to work, in the company of their loved ones. But do we have a solution to their hardships?

It is painful to think there is no ending to the stories we hear about migrant workers.

That is why as an artist, as Nora Aunor, together with all members of this play, will continue to tell stories about their lives. As long as they are oppressed, as long as the authorities are feigning deaf [to their stories and complaints], until the time comes that all DH from whichever part of the world will come back to the Philippines to embrace and reunite with their loved ones.

So their lives will have a good ending. (translation mine)

These pronouncements put in critical relief the artistic, social, and political commitments that Aunor bears out. First, a furious Aunor articulates a kind of unity with the domestics for whom she proxies and whose lives she portrays in $D H$. In speaking for and about Filipina migrant workers, the play's lead actress becomes the vessel of memories of people like Noemi, Fe, and Dolor. Second, the Superstar does not only express strong affective registers damning to social institutions, but also proclaims herself an enemy of the Philippine state. If Aunor's biography is evaluated, this polemical posturing against the government in 1992 and 1993 is not surprising at all, especially because the Superstar has always been known for criticizing national leaders, like when she faced the crowd during the second People Power Revolution in 2001 to testify against the physical violence she had experienced from her former leading man in show business, the then besieged President Joseph Ejercito Estrada. This so-called betrayal was something that she later apologized for to the deposed, jailed, and pardoned former head of state, a suspicious gesture for which the Superstar was scorned, very much like how she was damned by many, including her most ardent fans, for supporting leaders like Marcos (i.e., in the snap elections of 1986) and Gloria Macapagal-Arroyo. 
But Aunor finds ways to redeem herself from the most embarrassing career decisions she makes. She eventually regains her value and popularity, like when she proclaims in the ending of $\mathrm{DH}$ a utopic homecoming, a proposal contrary to the nation-state's commodification of its laboring citizens abroad. This declaration leaves the play open-ended, a la the Brechtian mode of theater-making. In strongly declaring a critical view against the state and the institution of the family, Aunor's concluding remarks go against a finale that perpetuates social values that evolve from what Bertolt Brecht calls "the fodder principle" (34). They do not complacently accept what is called, in the words of Brecht, "the society of the day" and the things that keep it going (34). When Aunor uses $D H$ as a venue to critique the Philippine government for its irresponsibility in handling issues of migrant workers, and to express her wish to see all domestic workers safely back in the homeland, she may be radically threatening the apparatus of a theater whose main social function is to reproduce hegemonic norms. She, too, may be altering a conservative theater through Brechtian means of rousing the audiences to think and act, recognize and study the evils of society, and assess and change themselves in the process. In all this, $D H$ 's final plea for a telos of return is deemed to be the peak of Aunor's performance as well as the very core of Lee's play.

Aunor is indeed the "performative vessel" intermediating-that is, intersecting, transmitting, and transforming-on the one hand, the theater world for which she becomes its primary spokesperson, and on the other hand, the society whose conceptualizations of labor, nationality, and citizenship are deemed fit for enactment on PETA's stage. Aunor does not only actively play as the central point at which stage and society converge and are magnified as constitutive parts of a larger totality; she, too, alters and is altered by the very social relations that her figure critically and productively mediates. What, then, makes the Superstar a favorite of theater and film practitioners with nationalist agendas? Given Aunor's biography, political affiliations, filmography, and performance in $D H$, how does the actress intertwine the melodramatic and the migratory?

$D H$ was conceived for Aunor. When the theme of migration was chosen for staging, PETA selected the Superstar as the singular actress who could embody the issues of the social phenomenon with skill and intelligence. Lee admitted that the national theater group gave him two requirements in writing the play: "First, Nora Aunor was to play the lead role. Second, the play shall have to tackle the lives of Filipina domestic helpers in Italy, Spain, Egypt, and Hong Kong" (Philippine Educational Theater Association, "DH: Domestic Helper Souvenir Program” n.p.). The link between PETA and the Superstar was not only solidified by commercial strategies but also by artistic commitments shared between the actress and the institution. Newspaper writer Mars Cavestany, Jr. notes that "the country's premier theater company ... has likewise used her superstardom to her very own as well 
as the organization's fullest advantage. A case of mutually beneficial undertaking, this!" (Cavestany n.p.).

Interestingly, Aunor herself may be recast as a migrant figure, especially in light of the many "displacements" she had experienced as a struggling young vendor of food and water in a train station in Bicol; as a dayo in the Metro which she eventually charmed through her captivating voice and figurine frame; and as a talent of national stature and as the anointed "people's artist," whose acting prowess is considered by many as "international" and "global" in scale. Her life characterized by social motions traverses but also transforms the spheres of the local, the national, and the foreign, in its encounters with poverty, in its gamble with fate, and in its realization of dreams made viable through strategic compromises with star studios and mass followings. In considering Aunor's figure as migratory, very much like the characters of Noemi, Fe, Dolor, and Loida, what is emphasized is the Superstar's agency to struggle and endure, her willingness to disseminate the techniques of her enduring body, and her ability to extricate herself from controversies and failures and resurface with renewed career possibilities accordingly. Critics have pointed out that these biographical details bear their traces in the face, the voice, the physique, and the personality of the actress who, in the eyes of her followers, may best personify servitude (pagsisilbi), suffering (paghihirap), grief (pagdadalamhati), endurance (pagtitiis), risk (pakikipagsapalaran), and labor (pagtratrabaho/ pagtataguyod).

Aunor, then, is perhaps the only member of Philippine show business who most capably essays the melodramatic, the migratory, the marginal, the domestic, and the diasporic all at the same time. She remains the most accepted actress in these aesthetic and social molds, not only because of her sheer acting ability and the trutheffects it capably produces, but also because of the parallelisms drawn between the star and the subjects on which this stardom stands and from which it emerges (Lim 65; Tadiar, "Noranian" 63). In the films Atsay and The Flor Contemplacion Story, as it is in the theater production $D H$, Aunor is not only confined to the role of babaeng martir or the slave-turned-heroine (Tadiar, "Noranian" 62). Nor is she restricted to the melodramatic female protagonist who takes hopeful passage from local/urban/national spaces of destitution to diasporic spaces of initially optimistic but ultimately failed futures. Instead, in all these portrayals of women entrapped within certain political economies, what Aunor demonstrates is that through the trappings of theater and cinema, she can exemplify as much as empathize with the aspiration and anguish of the people (Flores, "Dissemination" 82), especially because, as Tadiar has observed, "her aura as Superstar derives from her status as simultaneously being beyond the common tao and being of the common tao" ("Noranian" 63). The efficiency of Aunor as Superstar, then, cannot only be attributed to the technical skill she possesses and that enlists her in the roles she 

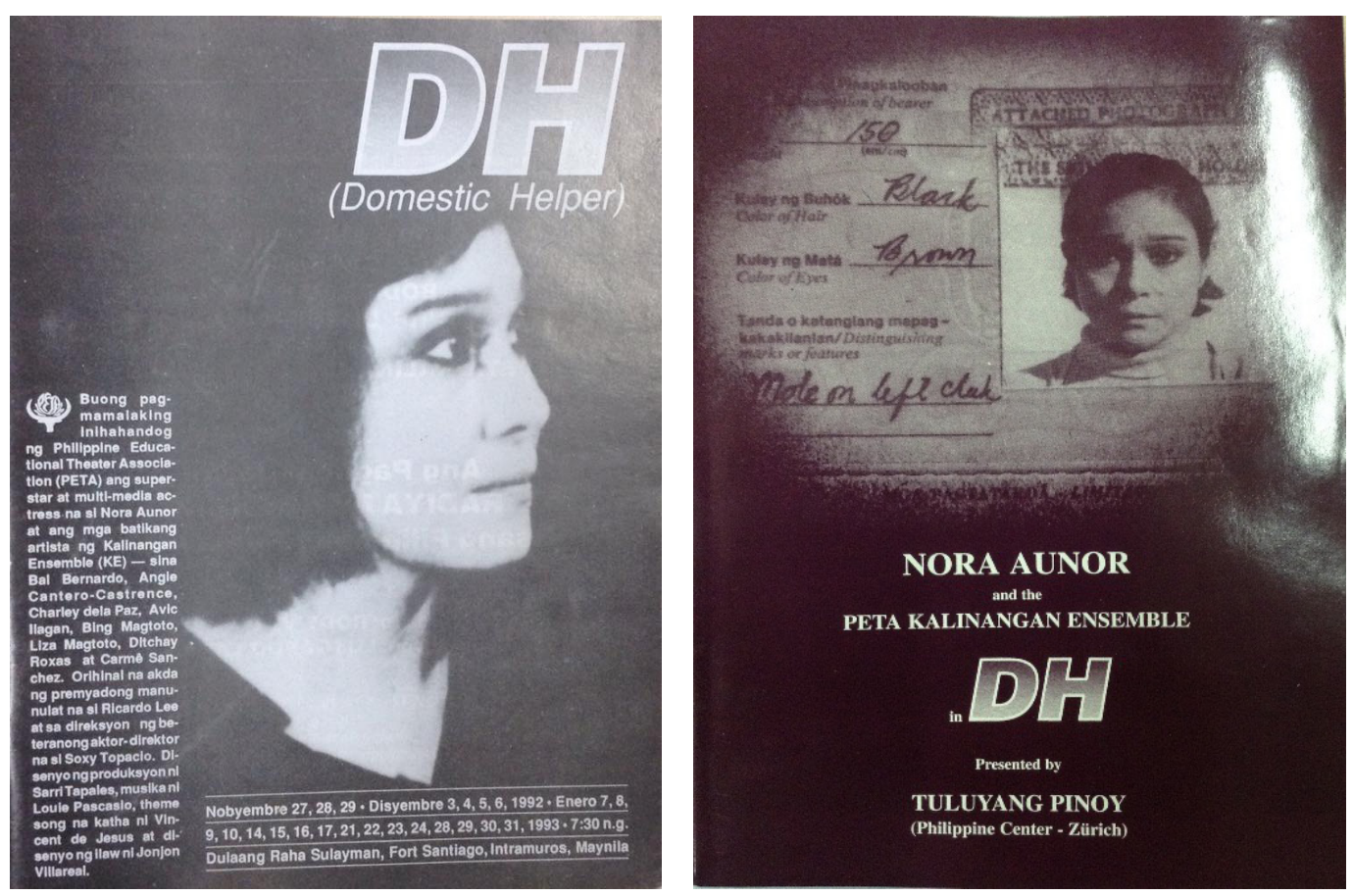

Figs. 8 and 9. Front covers of two souvenir programs of DH show the play dates and the coverage of PETA's theater production. Photo courtesy of the PETA Library and Archives.

masterfully brings to life; instead, something organically affective is what binds the life story of Aunor to her artistry, to her cinematic characters, to her personas, and to her relations with the people of the land.

Like the marginalized people, specifically domestic helpers and other types of laboring women, whose embodied sufferings propel personal dreams and keep afloat national life, Aunor is also the flesh, blood, talent, and energy sustaining numerous aspirations of multi-sectoral fan bases that the Superstar has engendered over the years. A national republic of images and icons is made operational through the seasoned actress's far-ranging iconography, filmography, discography, theatrography, and televisuality. In this scheme of comparisons, Filipina domestic helpers and Aunor, while uneven in their social status, may suggestively be interlinked precisely because of their contributions to Philippine society generated via the instrumentalization of their bodies, their connections to marginal(ized) origins, their itinerant routes, their aspirations for redemption and prosperity, and their susceptibility to a perennially precarious life. 

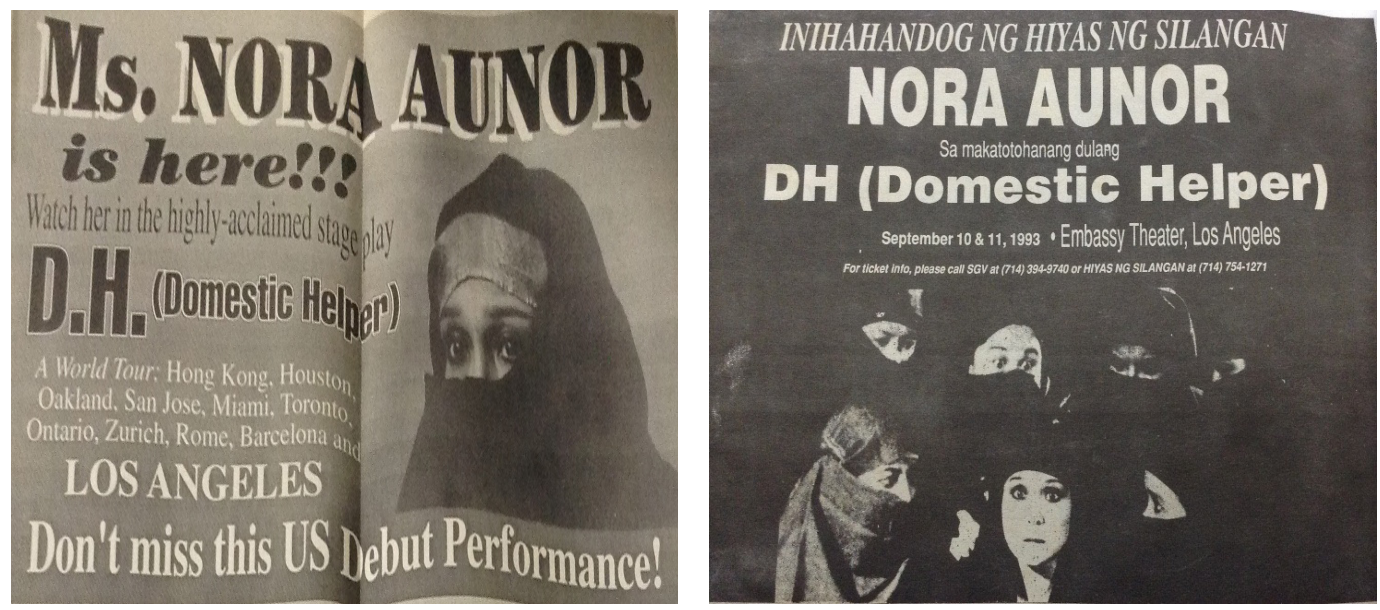

Figs. 10 and 11. Two sample publicity materials from DH's run overseas center on the image and star figure of Nora. These show how the Superstar serves as the ultimate invitation to DH's theater. Photo courtesy of the PETA Library and Archives.

The term "mass hysteria" that critical scholarship uses to describe this devotion deserves emphasis, precisely because it is at once reflective, constitutive, and supplemental of the very radicalism that both Aunor's person and persona manifest in many ways. In the context of $D H$, the very suffering that domestic helpers experience is the very inspiration of the final monologue that the Superstar launches against the nation-state. There is something hysterical in the actress's embodiment of the roles of activist and representative speaking for languishing domestic helpers all over the world, to the degree that she arrogates upon herself, with acting as her medium and the theater as her forum, the task to critique, resist, and subvert the Philippine government. It is in the contiguity of her roles as actress, $D H$ character, and advocate that Aunor evokes a semblance of hysteria and demonstrates a radical edge.

Aunor's career in the early 1990 os had already been much declared on the decline, so the stage which she graced and to which she was warmly welcomed might well have saved her from oblivion and gave her once again public visibility. In the purported coup de theater of $D H$, what the journalist Cavestany called "lilliputian singer-actress with definitely gargantuan talents" had another shot at repatriating, so to speak, the fame that had seemed to have already migrated at that point. It was via this theatrical venture that supporters, fans, and the press egged Aunor to play it again and to "prove to [the industry] that an honest to goodness superstar ay hindi malalaos (is inexhaustible)" (Cavestany n.p.). And indeed, like the performances she delivered in her prize-winning films, the Superstar did not disappoint her audience in $D H$ as she, according to the writer Muni Zano, "proved 
her mettle much like a multi-faceted gem . . . bright, clean and sharp: as a slave, a rape victim, a maid, a vagrant, a cheat and a distraught mother. Each character was keenly defined" (n.p.).

Through the acting vehicle that is $D H$ and through the performative vessel that is Aunor, issues of domestic labor and the stardom of the Superstar seemed to have gained more national and international currency at this juncture. For example, the spokesperson of a group of housewives, who categorized themselves as Aunor's fans, was even quoted to have stated: "Dahil sa mga ginawa ni Guy³ sa PETA ... nalaman namin ang ibang problema sa buhay na ito. Hindi naman kami mga ignorante bagama't hindi kami nakatapos ng pag-aaral. Kaya lang, mas naintindihan namin ang ilang problema ng bansa" (see "Relevant' Stars” n.p.) [Because of what Guy did in PETA ... we learned about other problems in this life. We are not ignorant, even if we were not able to finish our studies. But then, we have understood the problems of the country more.] The Superstar's comeback to the theater had also impelled her fan base, particularly the Grand Alliance for Nora Aunor Philippines or GANAP, to plan a massive protest in Liwasang Bonifacio not only to instate the Superstar as the people's artist, but also to put pressure on a government that was insensitive to the problems of labor migration in the country. While Aunor appealed to her followers to submit the course of things to the procedures of the court and the law, a show of force was boldly made apparent in that socio-historical occasion: "Marami anilang sasama sa pagtitipun-tipong ito. Hindi lang, ayon sa kanila, mga Noranians ang magmamartsa sa liwasan kundi mga magsasaka, mangingisda, mga katulong, propesyunal na mulat, mga estudyante at iba pang nagmamalasakit na sector ng lipunan, para sa kapakanan hindi lang ni Nora kundi sa mga naapi at niyuyurakang antas ng lipunan na walang puwersa na masatinig ang kanilang mga hinaing sa pamahalaan" (Villasanta n.p.). [They say a lot will join this gathering. According to them, it is not only the Noranians that will march to the plaza but also the fishermen, the maids, the enlightened professionals, the students, and other concerned sectors of society, for the sake not only of Nora but all the oppressed that do not have the force to voice their grievances to the government. $]^{4}$

Accounts that highlight Aunor's acting and the massive number of people she gathers from different sectors of society through her performances are vital to a cultural analysis of $D H$. For one, they indicate the very reception that audiences have toward an acting life or a life acted out. For another, they magnify the social power of art to make something visible, something collectively forceful. What is more interesting in the above-mentioned documentations, however, is the enunciated equivalence that Aunor's fans created between their idol and the socalled "wretched of the earth." If Aunor's talent in $D H$, as it was in her films, made manifest the pang-aapi, pagkayurak, or pagkapipi of the marginalized people who comprise most of her most enduring supporters, these fans, for their part,

Kritika Kultura 35 (2020): 244-255 
extend their devotion to and defense of their revered icon from screen to stage to reality. In registering support for their Superstar, for their own kind, and against the government, these followers script their affects and the formation of their critical communities, all of which propel and are propelled by Aunor's stardom, her moving image in the cinema, and her live presence in the theater. Moreover, in the consolidation of devotees within performative and political contexts, there, too, is the transformation of the public arena, the reevaluation of the polity, the appropriation of talent, the re-functioning of the celebrity, and the re-signification of the aesthetic mode of melodrama within the question of migration.

How, then, did DH concatenate "a melodrama of migration"? If the said aesthetic mode normatively features "strong emotionalism, moral polarization and schematization, extreme situations and actions, overt villainy, persecution of the good, and a final reward for virtue, dark plotting, suspense, reversals of circumstances, and finally, an experience of wholeness through monopathic emotion" (Majithia 6), how did the nationalist vision of $D H$ and PETA with regard to migration re-signify the melodramatic? If the histories of theater, film, and television cast melodrama as a "marginal, ephemeral form of 'illiterate' popular drama ... organized around a strikingly formulaic set of affective techniques and conventions" (Buckley 429-430), how did DH re-appropriate melodrama's popular and ideological tendencies in order to articulate critiques against the ruling state and the natural(ized) order of things? In other words, how did the play utilize conventional elements of melodrama, the "imagination of the melodramatic," and reconfigure them, to use the words of cultural critic Sheetal Majithia, as the aesthetic mode's "paradoxical potential"? Inasmuch as giving prominence to the experiences, emotions, consciousness, and activities of female subjects has been attached to the workings of melodrama (Dissanayake 2), the melodramatic mode has also been known for inscribing a patriarchal ideology and for further aggravating the sufferings of women. In the world of Filipino melodrama, film scholars Teresita Herrera and Wimal Dissanayake have noted that

[t]he female becomes an object of male gaze as her subjectivity is denied, and any attempt to destabilize this widely circulated image results in her being stigmatized as treacherous, sinister, and possessed of an unassuageable sexual appetite, which could dismantle the existing social order. Being a product of the male gaze in the cinematic representation, she continues to be enchained as an object of male voyeurism. Efforts at escaping her condition only result in tragedy. (218-219)

The objectification of women within patriarchal arrangements and diasporic dispensations is what $D H$ exploits and revises in its foregrounding of the lives of Noemi, Fe, Dolor, and Loida. While other “complicit women's melodramas" are ultimately produced from a patriarchal position, even or especially if their plotline 
sees women as central (Kaplan 13), PETA's melodrama of migration emphasizes the complicated contexts of women who are placed in patriarchal contexts. While complicit melodramas perpetuate narratives that encourage women to seek endings in the spheres of romance or "in the safe confines of the imaginary sphere of art, where nothing can really now harm them" (13), $D H$ by contrast breaks these romantic illusions and further implicates the stage production, its lead actress and other cast of characters, and its audience in the moral, physical, and material misery in the nation and the diaspora. While normative melodramas revel in sordidness and sensationalism (Dissanayake 1), DH in contrast creates cultural perceptions of diasporic suffering as well as spectacles of injured migrant beings in order to disturb the consolidation of hegemonic power and the prevalence of bourgeois art that looks at institutional practices as neutral, natural, and objective.

Placing melodrama within the Brechtian mode, which allows interruptions, simultaneities, and reversals to be interspersed within what would otherwise have just been a non-ironic linear plot, $D H$ puts forward dark figurations of women migrants, on the one hand, and "messes up" conventional realist images, on the other. This melodrama does not only engender a representational project but also stimulates "affective reason" or "ethical knowledge" that teases out realist accounts of migration, homogeneous conceptions of progress in the diaspora, and "teleological linearity of official state narratives" (Majithia 2). Furthermore, the melodramatic mode that is re-functioned within Brechtian techniques of theatermaking provides a second look at cultural, ideological, and theatrical constructions, to ensure that spectacular images and ideologies that theater espouses on stage do not go unchallenged.

This inflection of the melodramatic with the migratory begs the question: do melodramas on migration inspire audiences to position themselves against or reflect upon the inhumane conditions that Filipino migrant workers experience in both the nation and the diaspora? For $D H$, this kind of critical audience reception is assured by the progressive stance of Aunor and prompted by the nationalist vision of PETA.

Aunor's emphatic embodiment of an excessively dramatic text on women's migrant labor stimulated fans in the Philippines and abroad to weigh in on the issue at hand. At the same time, her sustained critique against the Philippine state, her participation in the cause of migrants, and her accessibility to a marginalized sector further established her relevance as an icon, an activist, and an artist from the entertainment industry in the country. It is documented that $D H$ was envisioned to take cinematic and televisual incarnations, something that while unrealized, could only lend credence to how PETA considered tapping into the trimedial and transmedial nature of Aunor's reign as the country's undisputed Superstar.

Kritika Kultura 35 (2020): 246-255 
Even Aunor was open to the idea: "Kung maisasapelikula, lalong lalawak ang manonood. Maipamamalas sa ating kababayan ang hirap na tinitiis ng ating mga kababayan sa pagpasok na katulong sa ibang bansa para masustentuhan lamang ang pamilya sa Pinas.... Malalaman ng ating mga kababayan ang mga kabiguan ng isang magpapakahirap na katulong sa ibang bansa na wala rin palang mapapala pagkatapos..." [If made into film, viewership would widen. It would be able to showcase the hardship that our fellowmen endure as they enter domestic work in other countries, in order to financially help their families in the Philippines .... Our countrymen will know the failures of a suffering domestic worker abroad who will not achieve anything in the end $]^{5}$ (in Blones n.p.). This plan indeed suggests that PETA was relying on Aunor's circulation and marketability in various fields of visibility. Her presence gave $D H$ more gravitas and made it more believable to the masa, to the culturati, and to the theatergoers who were not totally unaware of, but were indirectly linked to, the Superstar's fans. Even at a time when Aunor's career in showbiz was pronounced by several quarters as down and out, it was only the Superstar who could "truthfully" accomplish the acting of the social history of migration and meet the aesthetic requirements of melodrama.

PETA made sure that the "melodrama of migration" could still carry out agentive potentialities through its primary aesthetic and technical qualities. From the production staff notes, a discourse of affective agency may be discerned, particularly from the musical director Louie Pascaso's explanation regarding the play's pervading mood through an "uyayi" or a folk lullaby that aimed to conjoin fear and compulsion between child and woman. The technical director, Jonjon Villareal, who orchestrated the lighting design to suit the play's dramatic moments, claimed that he also wished to come up with "living" migrant geographies in Italy, Cairo, Hong Kong, and Barcelona. "Lullaby-pervaded musical direction," "memory-laden theme song," and "life-giving" light instruction-these descriptions of technical transactions were used by PETA's production team perhaps to uplift the problem of migration through deft use of the technologies of light and music.

If "melodrama" comes from the Greek word melos, meaning song, and originally denoted a stage play accompanied by music (Dissanayake 1), then DH's music sought to at once evoke lamentation and stir up empathy for others. This musical arrangement came into life especially through the Superstar's contralto voice that registered its sound as an elegy to the heroism of Filipino domestic helpers whose despair Aunor also communicated into song. In "Sulat ni Inay" [Letter of Mother], whose lyrics Lee wrote and whose music Vincent de Jesus produced, Aunor would sing not only the relationship between a migrant's domain in the homeland and her dissemination in the diaspora, but also the inseparable oneness of mind, heart, and flesh between a yearning mother and her left-behind child-very much like Noemi to her ailing daughter, as well as Dolor to her prodigal son. 
Kamusta ka, mahal kong anak?

Limang taon na tayong magkawalay

Di ko na nakita ang iyong paglaki

Di nabantayan sa malamig na gabi

Kahit ako'y nasa bansang dayuhan

Lagi kang laman ng aking puso

Lagi kang kasama sa mga dasal ko

Darating ang araw magkikita muli tayo

Refrain

At gaya ng dati sa araw ng Pasko

Magtatagpo tayo sa mga bituin

Tumingin ka sa langit at gayon din ako

Kislap sa mata'y magniningning kahit magkalayo

Hanggang dito na lamang... mga yakap at halik ...

Laging nagmamahal, ang iyong Inay

How are you, dear child?

We've already been separated from each other for five years

I have not been able to see you grow

Not watched over you in cold nights

Even if I am in a foreign country

You always fill my heart

You're always part of my prayers

Someday we will meet again

Refrain

And like before on Christmas Day

We will meet in the stars

Look at the sky and so will I

Shine in your eyes becomes brighter even while we're away

So long... hugs and kisses...

With much love, your mother (translation from source)

In the Hong Kong tour of $D H$, where the play was reported to have failed to draw capacity crowds in the Lyric Theatre, the biggest venue in the Hong Kong Academy of Performing Arts, largely due to poor promotion and steep ticket price (Pecho n.p.; De Guia n.p.), it was still this melodrama of migration that moved the audience into affinity and affection, into laughter and tears. According to newspaper writer Ernie 
Pacheco, "almost everybody in the audience was able to identify with the characters depicted in 'D.H.' How they yelled names of their friends or fellow domestic helpers every time they encountered familiar characters and situations" (n.p.). Among the audiences of $D H$, there was irrefutable emotional force in the conjunction of melodrama and migration as much as there was immediate identification with migrant sufferings and heroic sentiments that were kept in view via melodramatic spectacles. And so, the universe of theater, like the constellation done by film or cinema, and the figuration of a celebrity as a domestic helper, must be viewed as cultural procedures that transform "awa (pity) into damay (commiseration) or pakikidalamhati (sharing of grief) and finally into pakikiisa (solidarity)" (Flores, "Dissemination" 85).

As previously mentioned, the affective route of this melodrama of migration concludes not only by centering on the sufferers of systematic labor migration but also by directing the blame for this suffering or victimization to the Philippine state. In this sense, "melodrama's challenge lies not [only] in confronting how things are, but [also] in asserting how they ought to be" (Grimstead and Vicinus, qtd. in Sen 214). Aside from capturing "little lives [that slip] through the loosening interstices of a society in decline," presenting "a wrenching picture of people being swept off from their marginal paradise only to find out that they are unwelcome and unable to build their private utopias," and addressing "us Filipinos [who are] similarly trapped in that twilight between wild dreams and dashed hopes" (Abejo n.p.), DH makes the final claim that what cultural studies scholar Rolando Tolentino refers to as "the export of global national domesticity" ("Globalizing" 425) is exploited by a negligent government and that the theater audience should act to reverse worsening situations.

However, while the nationalist dimension, the critical approach to art and politics, as well as the purported telos of homecoming are passionately advocated in Third World theater industries and other cultural institutions, there are critics who nonetheless push the limits of these fundamental discourses of the nation so as to unsettle their totalizing tendencies and their "singular narratives of consciousness" (Lowe 39). Abejo, for example, critiques the limits of Lee's project, particularly the glaring absence of retribution or redemption in the play. He writes: "And whether or not each one has a better chance of coming out more than a loser is something that the play has stopped short of doing. Maybe because $D H$ is a play that tries too much to imitate reality, it bows out from the latter's pernicious demands with a bland summation!" (n.p.). Additionally, some critics have said that the play's ending-which Abejo describes as "the folly of theater utopias"-cannot go past Aunor's belligerent interjection of a party-line against the Philippine government. While this definitive propaganda may bear some potency in registering a grievance against systemic dispersals of Filipinas from the country to the world, it also falls

Kritika Kultura 35 (2020): 249-255

(C) Ateneo de Manila University

<http://journals.ateneo.edu/ojs/kk/> 
short, in Abejo's estimation, in opening the creative imagination of the audience to the potentials, if not advantages, of migrant work, domestic labor, the nation, and the diaspora.

As PETA limits the play's ending to a telos of homecoming and reifies the nationspace as the ultimate destination of all migrant workers, it also strips off from migrant workers the opportunity to decide on their social motions. In this case, $D H$ 's procedure of theater-making may find itself contained within what the Asian American studies scholar Lisa Lowe calls "the horizon of an absolute totality and [within a presumption] of a singular subject" (39), thereby rendering homogeneous the experiences of the proletarianized, gendered labor force that the play seeks to figure.

While it is crucial to investigate this play's inadequacy in complicating its plotline by way of a discourse on the network of global labor and a deconstructive revaluation of the migration of Third World nationals, it is likewise important to analyze the corrupt nation-state to which the migrant returns. At the time of its staging, the play's melodrama, its attendant telescoping of the plight of domestics abroad, and its concluding nationalistic rhetoric may be regarded as a compelling counterpoint to bureaucratic and state-sustained practices on nation-building, which foreclosed "militant investigations" on institutionalized labor-out migration from the Philippines in order to create an impression of a peaceful land and a progressive Philippines in the 1990 .

While Aunor's calls to oppose the Philippine state, to form a nationally-stratified solidarity, and to elect the nation-space as the final destination for all migrant workers may be incompatible with a cosmopolitan sensibility and may inaccurately render labor out-migration in a totally bad light, they may also be evaluated as necessary components of an unresolved ending that articulates and critiques the irresolvable reasons Filipinos continue to leave the country at the expense of their familial relations, their dignity, and their safety. Aunor's nationalist calls also bring into focus the government's accountability in managing the exportation of migrant domestic workers and its responsibility in making the Philippines a more habitable society for its citizens who stay, leave, and return.

In $D H$, both the performative and the affective show that human migration is not an absolute, fixed, linear phenomenon producing passive and uncritical subjects such as migrant domestic helpers. There is a deliberate and conscious capacity to act and feel in a stage performance or theater production that works within and against a mobility that drives laboring subjects away from their nation. As Loida, Noemi, Fe, and Dolor have shown, migrant domestic workers may fall prey to undignified conditions and callous treatment in the diaspora and in 
industries of foreign domestic labor, but they may also be active, embodied, and self-aware agents persistently degraded or suppressed yet not without resistance and reflection.

Kritika Kultura 35 (2020): 251-255

(C) Ateneo de Manila University

<http://journals.ateneo.edu/ojs/kk/> 


\section{Notes}

1. According to PETA's Curriculum Director and former actor, director, and production designer Brenda V. Fajardo, "PETA is known for its commitment to the development of a people's theater that mirrors Philippine social realities-a people's theater for empowerment, a potent agent toward personal and societal transformation. Thus, PETA has used its creative ability to survive in spite of its perennial poverty" (181). Fajardo is also known to practitioners and scholars of Philippine theater for her conceptualization of an "aesthetics of poverty," which was PETA's predominant working philosophy for its scenic designs especially in the late 1970s. This aesthetic philosophy "implies that there is a sense of beauty which belongs to people who live in a condition of material deprivation" (181).

2. I am citing unclassified and undated archival materials-from newspaper clippings, to programs, to production notes-in the files of DH: Domestic Helper in PETA's Library and Archives. Most of the cited newspaper or tabloid clippings do not show their page numbers, unless stated otherwise in this essay. For instance, Alexis Abejo's piece does not carry bibliographic entries. In my 11 Nov. 2019 email correspondence with Abejo about his work, he shares that: "Actually, the essay was more like a production note or press release for DH: Domestic Helper. As a new PETA member at that time, I would be assigned to write short pieces for every major or mobile PETA production to be included and printed as part of the playbill. So this particular essay, 'The Folly of Private Utopias,' was just one of several that I had written for PETA which did not have any bibliographic detail simply because it was meant only as a publicity material."

3. "Guy" is Nora's nickname among her fans and peers in the entertainment industry.

4. Translation by author.

5. Translation by author. 


\section{Works Cited}

Abejo, Alexis. "The Folly of Private Utopias," PETA Library and Archives. Date unknown. Aguilar, Filomeno. "Ritual Passage and the Reconstruction of Selfhood in International Labor Migration." Sojourn: Journal of Social Issues in Southeast Asia, vol. 14, no. 1, 1999, pp. 98-139.

Aguilar, Delia. "Imperialism, Female Diaspora, and Feminism." The Red Critique: Marxist Theory and the Critique of the Contemporary, no. 6, 2002, pp. 1-23.

Blones, Virgilio C. “Ba’t di isapelikula ang DH?” Balita, 3 Sept. 1993.

Brecht, Bertolt. Brecht on Theatre: The Development of an Aesthetic. Edited and translated by John Willett, Hill and Wang, 1992.

Brooks, Peter. The Melodramatic Imagination: Balzac, Henry James, Melodrama, and the Mode of Excess. Yale UP, 1995.

Buckley, Matthew. "Introduction." Modern Drama, vol. 55, no. 4, 2012, pp. 429-436.

Butler, Judith. "Performative Acts and Gender Constitution: An Essay in Phenomenology and Feminist Theory." Theatre Journal, vol. 40, no. 4, 1988, pp. 519-531.

Cavestany, Mars, Jr. "Play it again, Nora!" Philippine Times Journal, 28 Nov. 1992.

Conquergood, Dwight. "Beyond the Text: Toward a Performative Cultural Politics." The Future of Performance Studies: Visions and Revisions. Edited by Sheron J. Dailey, National Communication Association, 1998, pp. 25-36.

Das, Veena. "Suffering, Theodicies, Disciplinary Practices, Appropriations." International Social Sciences Journal, no. 154, 1997, pp. 563-572.

--. "Language and Body: Transaction in the Construction of Pain." Daedalus, vol. 125, no. 1, 1996, pp. 67-91.

Derrida, Jacques. "Structure, Sign, and Play in the Discourse of the Human Sciences." Twentieth Century Literary Theory: An Introductory Anthology. Edited by Vassilis Lambropoulos and David Neil Miller, State U of New York P, 1987, pp. 35-58.

De Guia, Boy C. “Kung bakit mahina ang 'DH’ ni Guy sa HK.” People’s Journal, 5 July 1993.

Diamond, Elin. "Introduction." Performance and Cultural Politics. Edited by Elin Diamond, Routledge, 1996, pp. 1-12.

Dissanayake, Wimal. "Introduction." Melodrama and Asian Cinema. Edited by Wimal Dissanayake, Cambridge UP, 1993, pp. 1-18.

Fajardo, Brenda. "The Aesthetics of Poverty: A Rationale in Designing for Philippine People's Theater 1973-1986." Kritika Kultura, no. 15, 2010, pp. 179-194. Accessed 17 Mar. 2009.

Fernandez, Doreen. Palabas: Essays on Philippine Theater History. Ateneo de Manila UP, 1996.

Flores, Patrick D. "The Dissemination of Nora." Geopolitics of the Visible: Essays on Philippine Film Cultures. Edited by Rolando B. Tolentino, Ateneo de Manila UP, 20oo, pp. 77-95.

--. "The Star Also Suffers: Screening Nora Aunor." Kasarinlan: Philippine Journal of Third World Studies, vol. 16, no. 1, 2001, pp. 71-96. 
-.. "Colonial Posterities: Portraiture and the Face of the Modern." Kasarinlan: Philippine Journal of Third World Studies, vol. 22, no. 2, 2007, pp. 22-45.

Grewal, Inderpal, and Caren Kaplan. "Global Identities: Theorizing Transnational Studies of Sexuality." GLQ: A Journal of Lesbian and Gay Studies, vol. 7, no. 4, 2001, pp. 663-679.

Guevarra, Anna Romina. Marketing Dreams, Manufacturing Heroes: Transnational Labor Brokering of Filipino Workers. Rutgers UP, 2010.

Herrera, Teresita, and Wimal Dissanayake. "Power, Pleasure, and Desire: The Female Body in Filipino Melodrama." Melodrama and Asian Cinema, pp. 218-231.

Kaplan, E. Ann. "Melodrama/Subjectivity/Ideology: Western Melodrama Theories and Their Relevance to Recent Chinese Cinema." Melodrama and Asian Cinema, pp. 9-28.

Kleinman, Arthur, Veena Das, and Margaret Lock. "Introduction." Daedalus, vol. 125, no. 1, 1996, pp. XI-XX.

Kristeva, Julia. "Psychonalysis and the Polis." Twentieth Century Literary Theory: An Introductory Anthology. Edited by Vassilis Lambropoulos and David Neil Miller, State U of New York P, 1987, pp. 363-378.

Lee, Ricardo. DH: Domestic Helper. Typescript for PETA for 1992-1993 Commercial Staging.

Lim, Bliss Cua. "Cult Fiction: Himala and Bakya Temporality." Spectator, vol. 24, no. 2, 2004, pp. 61-72.

Lloyd, Moya. "Performativity, Parody, Politics." Theory, Culture \& Society, vol. 16, no. 2, 1999, pp. 195-213.

Lowe, Lisa. "Work, Immigration, Gender: New Subjects of Cultural Politics." Social Justice, vol. 25, no. 3, 1998, pp. 31-49.

Majithia, Sheetal. "Rethinking Postcolonial Melodrama and Affect." Modern Drama, vol. 58, no. 1, 2015, pp. 1-23.

Mojares, Resil. Waiting for Mariang Makiling: Essays in Philippine Cultural History. Ateneo de Manila UP, 2002.

Parreñas, Rhacel Salazar. Servants of Globalization: Women, Migration, and Domestic Work. Ateneo de Manila UP, 2003.

-.. The Force of Domesticity: Filipina Migrants and Globalization. New York UP, 2008.

Pecho, Ernie. "Staging of Nora Aunor's 'D.H.' in HK fails to draw capacity crowds." The Sunday Times, 2o June 1993.

Philippine Educational Theater Association. DH: Domestic Helper Souvenir Program. 1992-1993.

--. "PR Material." 25-31 Jan. 1993.

Pratt, Geraldine. Families Apart: Migrant Mothers and the Conflicts of Labor and Love. $\mathrm{U}$ of Minnesota P, 2012.

“'Relevant' stars." Philippine Times, 2 June 1993.

“RICKY LEE; Playwright of 'DH (Domestic Helper).” Weekend Balita, 22-28 July 1993.

"RICKY LEE: Playwright of 'DH (Domestic Helper)." L.A. Life, 5 July 1993.

Rodriguez, Robyn Magalit. "Domestic Debates: Constructions of Gendered Migration from the Philippines." The Scholar and Feminist Online, vol. 6, no. 3, 2008, pp. 1-14. 
Rosca, Ninotchka. "The Philippines' shameful export." The Nation, vol. 26o, no. 15, 1995, pp. $522-527$.

Samson, Laura et al. A Continuing Narrative on Philippine Theater: The Story of PETA (Philippine Educational Theater Association). Philippine Educational Theater Association, 2008.

San Juan, Epifanio, Jr. "Contemporary Global Capitalism and the Challenge of the Filipino Diaspora." Global Society, vol. 25, no. 1, 2011, pp. 7-27.

Sen, Krishna. "Politics of melodrama in Indonesian cinema." Melodrama and Asian Cinema, pp. 205-217.

Tadiar, Neferti X. M. "Domestic Bodies of the Philippines." Sojourn: Journal of Social Issues in Southeast Asia, vol. 12, no. 2, 1997, pp. 153-191.

--. "The Noranian Imaginary." Geopolitics of the Visible: Essays on Philippine Film Cultures. Edited by Rolando B. Tolentino, Ateneo de Manila UP, 200o, pp. 61-67.

-.. Things Fall Away: Philippine Historical Experience and the Makings of Globalization. Duke UP, 2009.

Taylor, Diana. Performance. Durham, Duke UP, 2016.

Tolentino, Rolando B. "Globalizing National Domesticity: Female Work and Representation in Contemporary Women's Films." Philippine Studies, vol. 57, no. 3, 2009, pp. 419-442.

Vierness, Abe III. “Ms. Nora Aunor as DH: A National Treasure.” TIMES, 27 Sept. 1993.

Villasanta, Boy. "Mga Noranians, gustong mag-rally sa Liwasang Bonifacio para sa 'DH.' Bandera, 2 Sept. 1993.

Zano, Muni. "Domestic (D.H.) Helper: A Review." Phil-USA News Tribune, 24-30 Sept. 1993.

Kritika Kultura 35 (2020): 255-255 